Article

\title{
Modeling of the Anaerobic Digestion of Organic Wastes: Integration of Heat Transfer and Biochemical Aspects
}

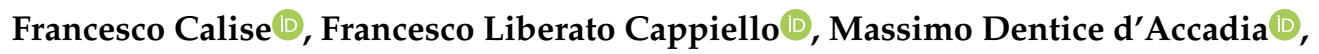 \\ Alessandra Infante and Maria Vicidomini * \\ Department of Industrial Engineering, University of Naples Federico II, 80125 Naples, Italy; \\ frcalise@unina.it (F.C.); francescoliberato.cappiello@unina.it (F.L.C.); dentice@unina.it (M.D.d.); \\ alessandra.infante.ai@gmail.com (A.I.) \\ * Correspondence: maria.vicidomini@unina.it
}

Received: 15 April 2020; Accepted: 16 May 2020; Published: 28 May 2020

check for updates

\begin{abstract}
The aim of this work is the development of a simulation model for the anaerobic digestion process of source-sorted organic fractions of municipal solid wastes. In particular, a detailed model simulating both biological and thermal behaviors of the process was developed. The biological model is based on the Anaerobic Digestion Model 1 (ADM1), which allows one to evaluate the dynamic trends of the concentrations of the main components and the biogas production as a function of the digester operating temperature. The work also includes a detailed thermal model which is developed considering the geometrical and structural features of the digester. The thermal behavior of the digester was also modeled, considering a purposely designed heat exchanger immersed inside the digester. Therefore, the thermal behavior of the process was evaluated by the well-known heat exchange equations and thermal energy balances. The combination of these two models is used to analyze the different possible operating conditions of the system. The model is also able to consider that the reactor operating temperature and the biogas production dynamically depend on a plurality of parameters: inlet hot water temperature and flowrate of the heating system, outdoor temperature, flowrate of organic fraction. The numerical resolution of the obtained differential equations and thermal balances of the model was carried out in the MATLABßenvironment. The result shows that the calculated biogas production is $0.132 \mathrm{Nm}^{3}$ per $\mathrm{kg}$ of OFMSW. In addition, the model also shows that the inlet hot water temperature must be increased by about $1.5^{\circ} \mathrm{C}$, to increase by $1.0^{\circ} \mathrm{C}$ the digester temperature.
\end{abstract}

Keywords: organic municipal solid wastes modeling; anaerobic digestion; reactor operating temperature; biogas

\section{Introduction}

The disposal of wastewater and wastes without treatment in water bodies and on land is no longer allowed for the majority of countries, as it produces harmful effects on the health of humans, animals and environment [1]. Since the wastewater treatment plants require large amounts of electrical and thermal energy, such systems are extremely intensive energy consumers [2]. The electrical demand for wastewater treatment represents about $1 \%$ of total consumption in almost all countries (Germany, Italy, etc.) [3]. In particular, the high energy consumption is mainly due to their heavy mechanical systems necessary to move and manage wastewater, such as pumps and aeration systems [4]. Pump systems account for more than $70 \%$ of the electricity consumption of such plants [5]. Due to the energy intensive processes involved with wastewater treatments plants, more energy efficient and sustainable treatments 
were developed during the past decades [6], e.g., wastewater may be converted into a stabilized waste in order to simultaneously produce some biological energy vectors (biomethane, biogas, etc.) [7]. Such gases can be further converted in combined heat and power plants [8], producing energy vectors (mainly electricity and heat) [9]. The obtained energy may be used both for the wastewater treatment plant internal loads and to supply energy to municipal district networks [10]. Biogas can be used as fuel for vehicles, after a cleaning phase and the upgrading to biomethane [11]. Therefore, according to this paradigm, wastes are no longer an energy and environmental issue, since they become a sustainable energy source. In addition, such an arrangement is also very attractive from the economic point of view, due to the savings in terms of waste disposal and to the incomes related to the produced energy [12]. In the framework of the biogas production, anaerobic digestion (AD) plants allow one to generate clean power and provide sanitation services by treating organic wastes [13]. AD consists of a series of reactions mediated by several groups of microorganisms that mineralize organic matter primarily to methane and carbon dioxide (biogas), in the absence of oxygen [11]. This process is widely used for the treatment of sewage sludge and is currently also being employed for the disposal of several types (municipal, industrial, etc.) of solid wastes [14].

The anaerobic digestion of OFMSW is a technology widely developed in Europe as it allows the energy recovery from organic matrices according to a perspective of a circular economy. The OFMSW definition varies from one country to another: in the USA, for example, OFMSW is considered as a mixture of food, garden and paper waste, while in the EU it is a mixture of waste from parks, gardens and kitchens [15]. It can be classified according to the collection strategy used: MS-OFMSW is the organic fraction mechanically sorted from unsorted urban waste and supplied to the biological process, while the SS-OFMSW comes from separate collection from domestic sources. The yield of the anaerobic degradation process of the OFMSW in terms of biogas production mainly depends on the specific features of the substrate and then on the plant configuration. The latter affects the performances of the process converting the biodegradable part of the substrate into biogas. The characteristics of the waste significantly depend on the collection technique. Cecchi et al. [16] noted that OFMSW from separate collection presents low total solids content (15-30\%) and most of them (70-90\%) are volatile solids: this means that most of the waste is characterized by putrescible material that will be subjected to anaerobic degradation. On the contrary, OFMSW from mechanical separation has a very high content of total solids, but volatile solids content is lower than $50 \%$ of TS: due to the high quantity of inert materials, most of the organic waste will be only partially involved in biodegradation and therefore a high amount of waste products will be obtained. Alvarez et al. [17] found that, in Catalonia, organic fraction of separated solid waste contained between $10 \%$ and $20 \%$ of undesirable material such as plastic bags, packing material, glass and textiles. In particular the organic waste coming from the door-to-door collection method has shown better quality than that from the street bin collection method. The work of Cesaro et al. [18] shows that unwanted materials accounts only for $12 \%$ of the total SS-OFMSW and consists mainly of plastics (78\%). In order to reduce the amount of non-digestable materials, a pre-treatment phase prior to AD could be expected. Household organic wastes are mainly treated with physical pretreatments, especially the mechanical ones [19]. These preteatments allow to reduce the risk for mechanical problems in the AD-plant and also to stabilize the composition of the inlet stream, but lead to the loss of organic material following the removal of waste products [20], as well as an increase in operating costs.

Since the middle of the last century, several modeling studies were presented to characterize the AD process, widely simulated in literature by using the Anaerobic Digestion Model 1 (ADM1). This model was developed by the International Water Association's (IWA) Task Group in the year 2002. The model is a universally suitable model for biogas simulations [21-23] and it includes 31 processes, described by 19 differential and 12 algebraic equations, with 24 dynamic states variables on 33 groups of fractions. The growth and decay of separate biomass fractions is also considered [24]. According to the equations of the general ADM1, several recent mathematical models were developed as reported in the following. As an example, Pastor-Poquet et al. [25] developed a novel model based on ADM1 
to simulate the process in case of high-solids $\mathrm{AD}$ for the organic fraction of municipal solid waste. With respect to the traditional 'wet' ADM1, their model adequately simulates the reactor content mass/volume variation that is significant in case of high removal of total solids. The model also includes the interrelationship between total solid removal and biogas production. Esposito et al. [26] defined a dynamic mathematical model that considers the influence of OFMSW particle dimension and of the organic loading rate on methane production and COD removal in the anaerobic co-digestion of OFMSW and sewage sludge. The anaerobic degradation of the sewage sludge is simulated using the ADM1, while the disintegration phase of the organic waste is modelled by a surface-based kinetic, in order to take into account that this process depends on the size of the composite material.

Anaerobic digestion is very sensitive to temperature fluctuations that may lead to a decrease in system performances and in biogas yield. The resulting temperature inside the digester depends on the heat exchange phenomena between the anaerobic digester and external environment and these are strongly affected by environmental conditions. For these reasons, AD simulation models must take into account the variation of the operating temperature according to boundary conditions (weather, OFMSW, etc.). The vast majority of the works available in literature are based on 0-D models which neglect any thermal gradients within the reactor, since this approach allows one to dramatically reduce computational times.

Axaopoulos et al. [27] developed a mathematical model in order to simulate the temperature variation of a swine manure digester heated with flat-plate solar collectors that are integrated into the digester cover. Model and experimental results show that this innovative design allows one to reduce the thermal losses of the reactor. Hreiz R. et al. [28] studied the influence of climatic conditions on an agricultural digester operating temperature by defining a detailed thermal model which includes the effect of some external factors, such as rainy events or the underground gradual warming during the AD process, on digester heat losses. Adouani et al. [29] analyzed the effect of working temperature and of the type of treated substrate on the performances of the digester of the previous work by using the ADM1 combined with a thermodynamic model.

The above reported literature review showed that most of the available studies are based on the modeling of the $\mathrm{AD}$, focusing on the biological and kinetic aspects of the process, by appropriately using the ADM1, or on the thermal aspects of the process, without taking into account that biological and thermal behaviors are strictly linked to each other. Therefore, to cover this lack of knowledge, the present paper focuses on the development of a reliable and accurate simulation model of the $\mathrm{AD}$, by considering both the biological and thermal modeling of the process. In particular, the final goal of the present work is the development of a fast and accurate simulation model to be subsequently integrated within a dynamic simulation tool, for the analysis of integrated systems including different types of renewables energies that can be used to meet the energy demand of the digester. Therefore, the main goal of this work is to determine the composition of biogas, paying special attention the amount of produced methane. In fact, the developed simulation code mainly aims at evaluating the energy and mass flows involved during the operation of the digester. For this reason, a simplified version of ADM1 is used, considering the forthcoming works where this model will be integrated into complex dynamic simulation models, including a plurality of additional components (biomethane vehicles, thermal storage tanks, solar thermal collectors, upgrading unit, etc.).

\section{Method}

This section presents the layout and modeling of AD treatment from organic fraction of municipal solid wastes for the biogas production, paying special attention to the biological and thermal processes. According to the best practices and to the scope of the paper mentioned in the previous section, the simplified version of the ADM1 is implemented. Note that the considered substrate is the source-sorted organic fraction of municipal solid waste, undergoing an appropriate separation phase before entering the digester to reduce the amount of non-digestible materials and also to stabilize the composition of the inlet stream. 
The procedure defining the geometrical and structural features of the digester as well as the design of the heating system is also reported. The developed thermal model is based on the well-known heat exchange equations and thermal energy balances. It is used to evaluate the biogas production as a function of the operating temperature of the digester.

As mentioned before, the developed model consists of an integration of two well-established techniques, namely: ADM1 for the calculation of the biological process performance, thermal model for the evaluation of the energy flows and temperatures involved in the system. In particular, the ADM1 is considered one of the most reliable techniques for the simulation of the AD and it is used in dozens of studies of validated vs. experimental results [30-32]. Similarly, the thermal model implemented in this paper is based on the log-mean technique, which is one of the most common methods in heat exchange processes [33] and which has been validated versus experiments in several studies. Therefore, the whole model can be considered validated, based on the sub-models validated versus experimental data in several previous studies. Unfortunately, the validation of the model as a whole vs. the experimental data is presently unfeasible, as the experimental data for such large reactors are not available.

\subsection{System Model}

\subsubsection{Biological Model}

The mathematical model of AD of the OFMSW follows the simplified approach of the ADM1 and includes biochemical and biological processes that are normally catalyzed by intra- or extra-cellular enzymes which act on the pool of available organic material.

A simplified approach is used, as the main reason of this work is the evaluation of the biogas production by the simplified version of ADM1, in order to couple the developed thermal-biological model with more complex component models, for example, thermal storage tanks, solar thermal collectors, upgrading unit, etc.

The model considers kinetics, stoichiometric coefficients and the concentrations of the following 13 components:

1. $X_{S}=$ simple particulate organic matter or macromolecular substrate; it consists of simpler organic material in particulate form and is represented by a mixture of carbohydrates, lipids and proteins with intermediate characteristics;

2. $X_{c}=$ composite particulate matter; it includes organic and inorganic material in particulate form contained in the waste and inactive biomass;

3. $S_{I}=$ soluble inert organic matter; it is soluble material not biodegradable via AD;

4. $X_{I}=$ particulate inert; it is particulate material not biodegradable via AD;

5. $S_{s o}=$ soluble monomers, that are grouped in a mixture of sugars, amino acids and long chain fatty acids (LCFAs) with intermediate characteristics;

6. $S_{o a}=$ organic acids that are grouped in a mixture of acids such as propionate, butyrate, valerate with intermediate characteristics;

7. $S_{a c}=$ acetate;

8. $S_{H 2}=$ hydrogen;

9. $S_{\mathrm{CH} 4}=$ methane;

10. $X_{\text {acid }}=$ acidogenic bacteria, acting during the acidogenesis;

11. $X_{a c e t}=$ acetogenic bacteria, acting during the acetogenesis;

12. $X_{\text {metaAC }}=$ aceticlastic methanogens bacteria, acting during the aceticlastic methanogenesis;

13. $X_{\text {metaH2 }}=$ hydrogenotrophic methanogens bacteria, acting during the hydrogenotrophic methanogenesis.

These concentrations are expressed in $\mathrm{kgCOD} / \mathrm{m}^{3}$ : the chemical oxygen demand (COD) measures the amount of oxygen required to completely oxidize all the organic and inorganic substances contained in a water sample to $\mathrm{CO}_{2}$ and $\mathrm{H}_{2} \mathrm{O}$, therefore, it indicates the total content of oxidizable organic and 
inorganic substances in the material to be treated. Figure 1 shows the modeled various stages of the AD process and the components involved.

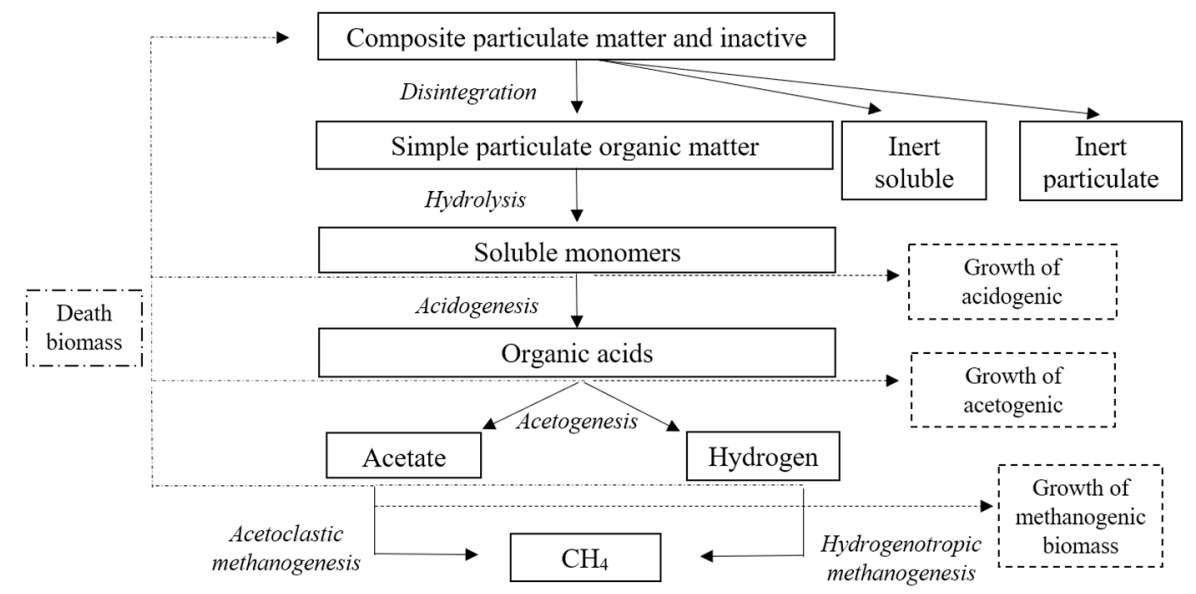

Figure 1. Steps of the AD process.

In Tables 1 and 2, the adopted equations in the model are written in matrix form: in the first column starting from the left, there are the different phases of the AD process, in the first row there are the components and in each cell the biochemical coefficients $\left(\alpha_{i, j}\right)$, describing how each component is involved in the different processes, in terms of components concentrations. The model presents 10 processes and 13 components. In Table 3 , the kinetics $\left(\varphi_{j}\right)$ for each process are summarized.

Table 1. Biochemical coefficients $\left(\alpha_{i, j}\right)$ for soluble components $(i=1-6, j=1-10)$.

\begin{tabular}{|c|c|c|c|c|c|c|c|}
\hline & Components $\rightarrow i$ & 1 & 2 & 3 & 4 & 5 & 6 \\
\hline & Processes $\downarrow j$ & $S_{I}$ & $S_{\text {so }}$ & $S_{o a}$ & $S_{a c}$ & $S_{H 2}$ & $S_{\mathrm{CH} 4}$ \\
\hline 1 & Disintegration & $f_{S I, X c}$ & - & - & - & - & - \\
\hline 3 & Acidogenesis & - & -1 & $\left(1-Y_{\text {acid }}\right)$ & - & - & - \\
\hline 4 & Acetogenesis & - & - & -1 & $f_{\text {Sac, Soa }} \times\left(1-Y_{\text {acet }}\right)$ & $f_{S H 2, \text { Soa }} \times\left(1-Y_{\text {acet }}\right)$ & \\
\hline 6 & $\begin{array}{l}\text { Hydrogenotropic } \\
\text { methanogenesis }\end{array}$ & - & - & - & - & -1 & $\left(1-Y_{\text {metaH2 } 2}\right)$ \\
\hline 7 & Decay $X_{\text {acid }}$ & - & - & - & - & - & - \\
\hline 8 & Decay $X_{\text {acet }}$ & - & - & - & - & - & - \\
\hline \multirow[t]{2}{*}{10} & Decay $X_{\text {metaH2 }}$ & - & - & - & - & - & - \\
\hline & & $\begin{array}{c}\text { Soluble } \\
\text { inert }\end{array}$ & $\begin{array}{c}\text { Soluble } \\
\text { monomers }\end{array}$ & $\begin{array}{l}\text { Organic } \\
\text { acids }\end{array}$ & Acetate & Hydrogen & Methane \\
\hline
\end{tabular}

Tables 1 and 2 can be read in the following way: the composite particulate matter $X_{\mathcal{C}}$ (column 7 ) is produced by decay of the different microbial families $(+1)$ and is reduced $(-1)$ during the disintegration process, with the formation of simpler particulate matter $X_{S}$, inert particulate matter $X_{I}$ and soluble inert material $S_{I}$, according to the respective stoichiometric coefficients $f_{i, X c}$ (row 1, columns 1, 8 and 9). During the hydrolysis phase, the concentration of organic particulate matter $X_{S}$ is reduced $(-1)$, with formation $(+1)$ of soluble monomers $S_{s o}$ (column 2), that are converted $(-1)$ into organic acids $S_{o a}$ (column 3, $1-Y_{\text {acid }}$ ) by acidogenic micro-organisms $X_{\text {acid }}$. During the acidogenesis the growth $\left(Y_{\text {acid }}\right)$ of acidogenic biomass (column 10) also occurs. The acetogenesis of organic acids (-1) by acetogenic biomass $X_{\text {acet }}$ leads to the formation of acetate $S_{a c}\left(f_{\text {Sac,Soa }} \times\left(1-Y_{\text {acet }}\right)\right)$, hydrogen $S_{H 2}\left(f_{S H 2, \text { Soa }} \times(1-\right.$ $\left.Y_{\text {acet }}\right)$ ) and new microorganisms $\left(Y_{\text {acet }}\right)$. During the acetoclastic and hydrogenotropic methanogenesis 
phases, respectively acetate (column 4 ) and hydrogen (column 5) are converted (-1) into methane $S_{\mathrm{CH} 4}$ (column 6) and carbon dioxide, with growth of the methanogenic microbial families (columns 12 and 13). Disintegration, hydrolysis and biomass decay are modeled through first order kinetics, the other reactions and the relative microbial growth are modeled with the kinetics of Michaelis-Menten and Monod, dependent, with Arrhenius' Law, on temperature.

Table 2. Biochemical coefficients $\left(\alpha_{i, j}\right)$ for particulate matter $(i=7-13, j=1-10)$.

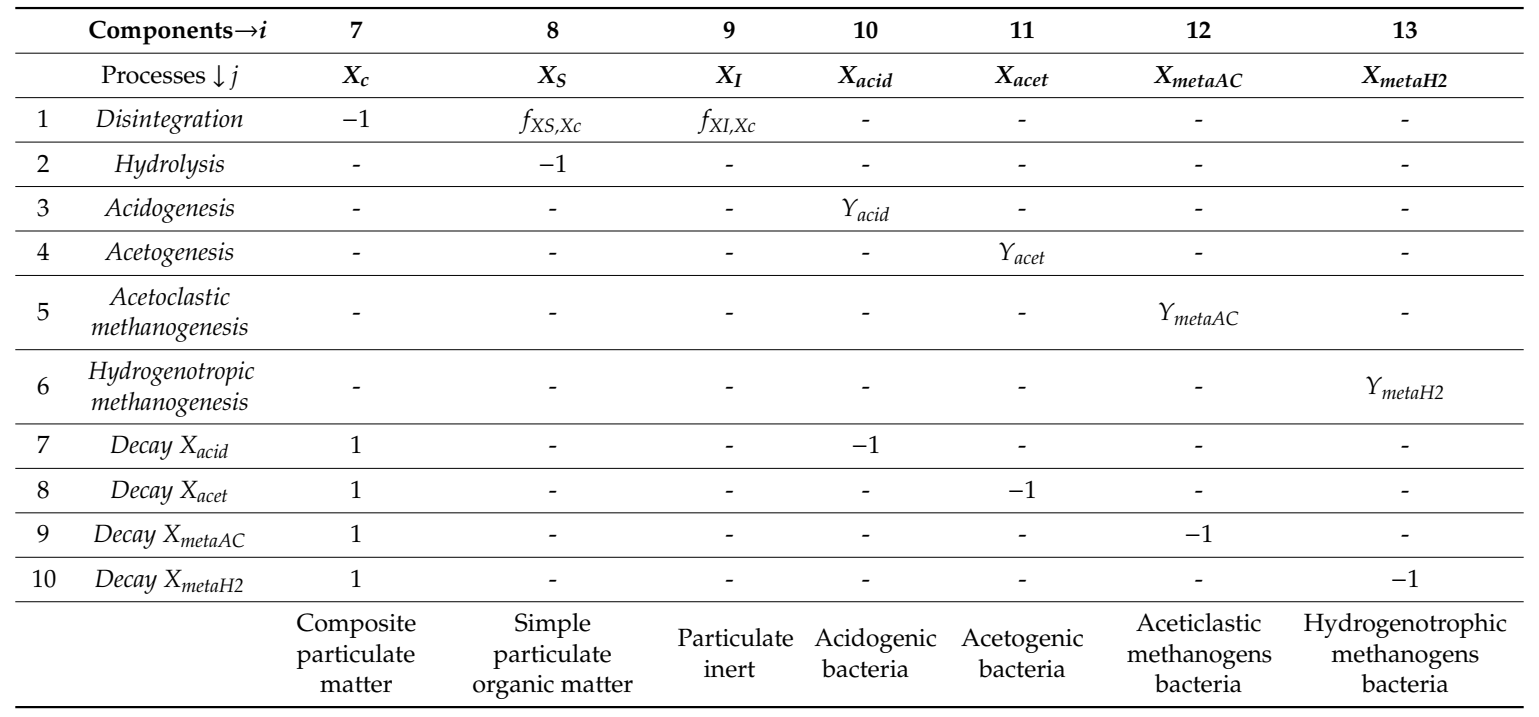

Table 3. Kinetic equations $\left(\varphi_{j}\right)$ of the process $j$.

\begin{tabular}{|c|c|}
\hline Processes & Kinetics $\varphi_{j}$ \\
\hline Disintegration & $k_{d i s} \times X_{c}$ \\
\hline Hydrolysis & $k_{h y d r o} \times X_{S}$ \\
\hline Acidogenesis & $v_{\text {max }, \text { acid }} \times\left[S_{\text {so }} /\left(k_{s, \text { acid }}+S_{s o}\right)\right] \times X_{\text {acid }}$ \\
\hline Acetogenesis & $v_{\text {max }, \text { acet }} \times\left[S_{o a} /\left(k_{s, a c e t}+S_{o a}\right)\right] \times X_{a c e t}$ \\
\hline Acetoclastic methanogenesis & $v_{\text {max }, \text { metaAC }} \times\left[S_{a c} /\left(k_{s, \text { metaAC }}+S_{a c}\right)\right] \times X_{\text {metaAC }}$ \\
\hline Hydrogenotropic methanogenesis & $v_{\text {max }, \text { metaH2 }} \times\left[S_{H 2} /\left(k_{s, \text { metaH2 }}+S_{H 2}\right)\right] \times X_{m e t a H}$ \\
\hline Decay $X_{a c i d}$ & $k_{d, a c i d} \times X_{a c i d}$ \\
\hline Decay $X_{\text {acet }}$ & $k_{d, \text { acet }} \times X_{\text {acet }}$ \\
\hline Decay $X_{m e t a A C}$ & $k_{d, \text { metaAC }} \times X_{m e t a A C}$ \\
\hline Decay $X_{m e t a H 2}$ & $k_{d, \text { metaH2 }} \times X_{\text {metaH } 2}$ \\
\hline
\end{tabular}

The model is implemented on a completely stirred tank reactor (CSTR) [34,35] and consists of 13 differential mass balance equations on the 13 components of the system that can be written as:

$$
\frac{d C_{\text {waste }, i}}{d t}=\frac{\dot{V}_{\text {in }}}{V_{\text {waste }}} C_{\text {waste }, i, \text { in }}-\frac{\dot{V}_{\text {out }}}{V_{\text {waste }}} C_{\text {waste }, i}+\sum_{j=1}^{10} \varphi_{j} \alpha_{i, j}
$$

where $C_{\text {waste }, i, i n}$ is the input concentration of the generic component $i$ contained in the waste; $C_{\text {waste }, i}$ is the concentration of the generic substrate $i$ in the reactor during the AD process; $\varphi_{j}$ is the kinetics of reaction $j ; \alpha_{i, j}$ is the biochemical coefficient of component $i$ in reaction $j$.

Neglecting the mass variation due to gasification, it is assumed that the input OFMSW flow rate is equal to the output digestate $\left(\dot{V}_{\text {in }}=\dot{V}_{\text {out }}\right)$ and that the volume occupied by the waste $V_{\text {waste }}$ remains constant. The system of differential equations is associated with the equations for the calculation of the 
obtained biogas flow rate. The gas methane flow rate is calculated by multiplying the concentration of gas formed in the waste by the volumetric flow rate of digestate leaving the system, while the total flow rate of biogas and carbon dioxide are estimated by establishing a hypothetical gas mixture composition. Further details are provided in Section 3.

\subsubsection{Thermal Model}

The thermal model consists of two heat exchange equations, i.e., the digestor's thermal balance equation and the heating system heat exchange equation, with two independent variables $T_{\text {digester }}$ and $T_{\text {out,water }}$. The heat exchange equations, solved with the algorithm "fsolve", are reported as follows:

$$
\begin{gathered}
\dot{m}_{\text {OFMSW }} c_{p, \text { OFMSW }} T_{\text {in,OFMSW }}+\dot{m}_{\text {water }} c_{p, \text { water }} T_{\text {in,water }}=\dot{m}_{\text {digestate }} c_{\text {, digestate }} T_{\text {digester }}+\dot{m}_{\text {biogas }} c_{p, \text { biogas }} T_{\text {digester }} \\
+\dot{m}_{\text {water }} c_{p, \text { water }} T_{\text {out }, \text { water }}+U_{\text {digester }} A_{\text {digester }}\left(T_{\text {digester }}-T_{\text {amb }}\right)+U_{\text {foundation }} A_{\text {foundation }}\left(T_{\text {digester }}-T_{\text {ground }}\right) \\
+U_{\text {cover }} A_{\text {cover }}\left(T_{\text {digester }}-T_{\text {amb }}\right) \\
\dot{m}_{\text {water }} c_{p, \text { water }}\left(T_{\text {in,water }}-T_{\text {out }, \text { water }}\right)=n U_{H E, n} A_{H E, n} \Delta T_{l m}
\end{gathered}
$$

It should be noted that the biogas and digestate flow rates are also unknown, as these quantities depend on the operating temperature of the digester. Since these flow rates were outputs of the biological model, a combination of the two kinetic and thermal models was carried out. In order to respect the mass balance, the digestate flow rate is given by the difference between the input waste and the output biogas. The results achieved in terms of biogas and digestate flow rate are calculated at the operating temperature of the digester.

The global heat transmission coefficients are calculated considering both the structural and thermal parameters. The digester walls' transmittance was calculated with the following equation:

$$
U_{\text {digester }}=\frac{1}{\sum_{i=1}^{n} \frac{s_{i}}{\lambda_{i}}+\frac{1}{h_{\text {est }}}}
$$

where $\sum_{i=1}^{n} \frac{s_{i}}{\lambda_{i}}$ is the sum of the conductive thermal resistances calculated as the ratio of the thickness of the various digester walls' layers to their thermal conductivity, while $h_{e s t}$ is the convective coefficient between the digester walls' external surface and the environment. The convective heat exchange resistance along the internal digester walls has been neglected since the reactor is mostly filled by the OFMSW which is a predominantly solid substrate. All data are summarized in Table 6 .

The digester foundations' transmittance $U_{\text {foundation }}$ has been calculated considering the layers of different material below the digester and neglecting the convective thermal resistance that occur along the surfaces in contact with the OFMSW and the ground. The transmittance of the top of digester $U_{\text {cover }}$ depends on type of cover chosen for the reactor. Further details can be found in the following section.

The heat exchanger global heat transmission coefficient is calculated as a function of water velocity and thermophysical properties. The convection coefficient $h_{\text {int }, \text { water }}$ along the coil internal side necessary to calculate $U_{H E}$ is determined with the following equation [36]:

$$
h_{\mathrm{int}, \text { water }}=\frac{\lambda_{\text {water }}}{D N_{H E, n}} \mathrm{Nu}
$$

where $N u$ is the Nusselt number, that can be expressed as a function of Prandtl and Reynolds numbers in the case of forced convection. It is calculated with Dittus-Boelter correlation [36], valid for turbulent flow, $0.7<\operatorname{Pr}<10$, ratio of coil length to coil diameter greater than 10 and fluid heating the pipe internal side:

$$
N u=0.023 \operatorname{Re}^{0.8} \operatorname{Pr}^{0.3}
$$


Considering that the developed model is a 0-D model, OFMSW is assumed at constant temperature and the thermal resistance between OFMSW and tube wall is neglected. Therefore, the overall heat transfer coefficient takes into account thermal resistance of water and conductive resistance of pipe. Two additional resistances may also be included into the equation in order to take into account the fouling in the inner side of the tube $R_{\text {fouling,int }}$ and the fouling on the outer side of the tube $R_{\text {fouling,est }}$, as shown in the a sensitivity analysis.

$$
U_{H E, n}=\frac{1}{\frac{1}{h_{\text {int, water }}}+\frac{S_{H E}}{\lambda_{H E}}+R_{\text {fouling,int }}+R_{\text {fouling,est }}}
$$

where $R_{\text {fouling,int }}=\frac{s_{\text {fouling }}}{\lambda_{\text {fouling }}}$.

Note that the real pipe diameter, assuming that fouling occurs along the whole pipe internal surface, is equal to:

$$
D N_{H E, n-\text { fouling }}=D N_{H E, n}-2 s_{\text {fouling }}
$$

The heat exchanger is simulated using the well-known log-mean temperature difference method. Here, the hot fluid is the water and the cold fluid is the OFMSW. Considering that a 0-D model the temperature of the OFMSW is assumed constant along the heat exchanger (this assumption is also supported by the fact that a fully mixed reactor is considered where the OFMSW is continuously mixed). Therefore, log-mean temperature can be calculated as follows:

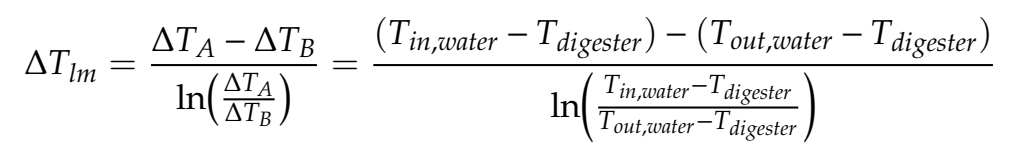

\section{Case Study}

In Table 4, a description of the different parameters included in the matrix including the kinetic equations $\left(\varphi_{j}\right)$ of the process $\mathrm{j}$ (Table 3 ) and their respective values is reported. Note that the maximum hydrolysis reaction rate is calculated as weighted average considering the incoming waste composition shown in Table 5.

The digester is designed as follows: for a 30-day HRT and a waste flow rate of 15,000 t/d, a reactor volume of $800 \mathrm{~m}^{3}$ is obtained, which is assumed to be filled by $\frac{3}{4}$ from waste. For a height of $5 \mathrm{~m}$, the diameter of the digester is approximately $14 \mathrm{~m}$.

In this study the digester is covered by a gasometric dome consisting of two PVC membranes anchored to the edge of the reactor: the external membrane forms the outer cover and has a fixed volume with a fixed height of $2 \mathrm{~m}$; the biogas is stored under the internal membrane, so the volume under this membrane changes because the amount of biogas varies during the process. Between the two membranes there is a chamber containing air in order to compensate the level variations of the internal membrane: by adding or extracting air, the chamber and biogas are kept at constant pressure, regardless of the quantity of biogas produced.

Most of the heat losses occur along at the gasometric dome. The total thermal resistance along the gasometric dome was calculated under the following assumptions: the biogas below the internal membrane remains stationary and its convective coefficient is fixed equal to $10 \mathrm{~W} /\left(\mathrm{m}^{2} \mathrm{~K}\right)$; the resistance in the air gap between the two membranes is fixed equal to $0.13\left(\mathrm{~m}^{2} \mathrm{~K}\right) / \mathrm{W}$; the membranes thermal resistance is negligible because they are thin and consists of plastic material with relatively high conductivity.

The structural and thermal parameters used for the calculation of the global heat transmission coefficients are shown in Table 6. Note that steel sheet thermal resistance in the calculation of digester walls' transmittance was neglected since its low thickness and high thermal conductivity. 
Table 4. Stoichiometric coefficients, kinetic parameters and rates.

\begin{tabular}{|c|c|c|c|}
\hline Symbol & Description & Value & Unit \\
\hline$K_{s, a c i d}$ & Half-saturation constant of the acidogenesis process & 0.5 & \multirow{4}{*}{$\mathrm{kgCOD} / \mathrm{d}$} \\
\hline$K_{s, a c e t}$ & Half-saturation constant of the acetogenesis process & 0.2 & \\
\hline$K_{s, \text { metaAC }}$ & Half-saturation constant of the acetoclastic methanogenesis process & 0.15 & \\
\hline$K_{s, m e t a H 2}$ & $\begin{array}{l}\text { Half-saturation constant of the hydrogenotropic methanogenesis } \\
\text { process }\end{array}$ & $7 \times 10^{-6}$ & \\
\hline$Y_{\text {acid }}$ & Yield of acidogenic biomass & 0.10 & \multirow{4}{*}{ - } \\
\hline$Y_{\text {acet }}$ & Yield of acetogenic biomass & 0.06 & \\
\hline$Y_{\text {metaAC }}$ & Yield of aceticlastic methanogens biomass & 0.05 & \\
\hline$Y_{\text {metaH2 }}$ & Yield of hydrogenotrophic methanogens biomass & 0.06 & \\
\hline$k_{d, a c i d}$ & First order decay rate of acidogenic biomass & 0.02 & \multirow{4}{*}{$1 / \mathrm{d}$} \\
\hline$k_{d, a c e t}$ & First order decay rate of acetogenic biomass & 0.02 & \\
\hline$k_{d, m e t a A C}$ & First order decay rate of aceticlastic methanogens biomass & 0.02 & \\
\hline$k_{d, \text { metaH2 }}$ & First order decay rate of hydrogenotrophic methanogens biomass & 0.02 & \\
\hline$f_{S I, X c}$ & Yield of $S_{I}$ on $X_{c}$ & 0.05 & \multirow{5}{*}{-} \\
\hline$f_{X I, X c}$ & Yield of $X_{I}$ on $X_{c}$ & 0.15 & \\
\hline$f_{X S, X c}$ & Yield of $X_{S}$ on $X_{C}$ & 0.80 & \\
\hline$f_{\text {Sac,Soa }}$ & Yield of $S_{a c}$ on $S_{o a}$ & 0.72 & \\
\hline$f_{S H 2, S o a}$ & Yield of $S_{H 2}$ on $S_{o a}$ & 0.28 & \\
\hline$k_{\max , d i s, 35^{\circ}}$ & Maximum disintegration reaction rate at $35^{\circ} \mathrm{C}$ & 0.5 & \multirow{6}{*}{$1 / \mathrm{d}$} \\
\hline$k_{\max , h y d r o, 35^{\circ}}$ & Maximum hydrolysis reaction rate at $35^{\circ} \mathrm{C}$ & 1.0156 & \\
\hline$v_{\text {max }, a c i d, 35^{\circ}}$ & Maximum acidogenesis reaction rate at $35^{\circ} \mathrm{C}$ & 30 & \\
\hline$v_{\max , a c e t, 35^{\circ}}$ & Maximum acetogenesis reaction rate at $35^{\circ} \mathrm{C}$ & 20 & \\
\hline$v_{\text {max }, \text { meta } A C, 35^{\circ}}$ & Maximum acetoclastic methanogenesis reaction rate at $35^{\circ} \mathrm{C}$ & 8 & \\
\hline$v_{\max , \operatorname{metaH} 2,35^{\circ}}$ & Maximum hydrogenotropic methanogenesis reaction rate at $35^{\circ} \mathrm{C}$ & 35 & \\
\hline
\end{tabular}

Table 5. Incoming waste composition.

\begin{tabular}{c|c|c|c}
\hline Symbol & Description & Value & Unit \\
\hline$\%_{\mathrm{Ch}}$ & Percentage of carbohydrates in the incoming waste & 0.55 & \multirow{2}{*}{ - } \\
\cline { 1 - 2 }$\%_{\mathrm{Pr}}$ & Percentage of proteins in the incoming waste & 0.20 & \\
\cline { 1 - 2 }$\%_{\mathrm{Li}}$ & Percentage of lipids in the incoming waste & 0.05 & \\
\hline$\%_{\mathrm{I}}$ & Percentage of inerts in the incoming waste & 0.20 & \\
\hline
\end{tabular}

The heat exchanger is designed to reach the set point temperature of digester $T_{\text {setpoint }}$ equal to $40{ }^{\circ} \mathrm{C}$ and assuming a reduction in water temperature from 55 to $45^{\circ} \mathrm{C}$. It consists of four high density cross-linked polyethylene coils, operating in parallel with a diameter of $2.5 \mathrm{~cm}$ and a length of each pipe equal to the perimeter of digester. The obtained rated total hot water mass flow rate necessary to heat the digester at the desired temperature is equal to $0.557 \mathrm{~kg} / \mathrm{s}$. Note that the value of the calculated parameters for the estimation of $U_{H E, n}$ will vary as a function of water flow rate, as shown in the sensitivity analysis carried out subsequently. 
Table 6. Digester and HE structural and thermal parameters.

\begin{tabular}{|c|c|c|c|}
\hline Parameter & Description & Value & Unit \\
\hline$s_{C L S, w}$ & Digester concrete walls' thickness & 0.2 & \multirow{10}{*}{$\mathrm{m}$} \\
\hline$s_{X P S-S L, w}$ & Walls' polystyrene insulation layer thickness & 0.1 & \\
\hline$S_{S T, w}$ & Stainless steel corrugated sheet thickness & 0.005 & \\
\hline$s_{C L S . f}$ & Concrete foundation thickness & 0.4 & \\
\hline$S_{X P S-S L, f}$ & Underground polystyrene insulation layer thickness & 0.1 & \\
\hline$s_{M G, f}$ & Underground concrete layer thickness & 0.5 & \\
\hline$s_{P V C}$ & PVC dome membranes thickness & 0.001 & \\
\hline$S_{P E-X a}$ & Polyethylene coil wall thickness & 0.0018 & \\
\hline$D N_{H E, n}$ & Rated pipe diameter & 0.025 & \\
\hline$L_{H E, n}$ & $\mathrm{n}^{\text {th }}$ pipe length & 44.84 & \\
\hline$\lambda_{C L S ., w}$ & Concrete thermal conductivity & 2.3 & \multirow{5}{*}{$\mathrm{W} /(\mathrm{m} \mathrm{K})$} \\
\hline$\lambda_{X P S-S L, w}$ & Polystyrene thermal conductivity & 0.036 & \\
\hline$\lambda_{M G ., f}$ & Underground concrete thermal conductivity & 1.6 & \\
\hline$\lambda_{P E-X a}$ & Polyethylene thermal conductivity & 0.38 & \\
\hline$\lambda_{\text {water }}$ & Coil water thermal conductivity & 0.65 & \\
\hline$\rho_{\text {water }}$ & Coil water density & 987.70 & $\mathrm{~kg} / \mathrm{m}^{3}$ \\
\hline$c_{p, \text { water }}$ & Coil water specific heat & 4.178 & $\mathrm{~kJ} /(\mathrm{kg} \mathrm{K})$ \\
\hline$\mu_{\text {water }}$ & Coil water dynamic viscosity & $565 \times 10^{-6}$ & $\mathrm{~Pa}^{*} \mathrm{~s}$ \\
\hline $\mathrm{Pr}$ & Coil water Prandtl number & 3.65 & \multirow{3}{*}{100} \\
\hline $\operatorname{Re}$ & Reynolds number & 12548 & \\
\hline$N u$ & Nusselt number & 64.46 & \\
\hline$h_{\text {est }}$ & External air convective coefficient & 25 & \multirow{3}{*}{$\mathrm{W} /\left(\mathrm{m}^{2} \mathrm{~K}\right)$} \\
\hline$h_{\text {int biogas }}$ & Biogas convective coefficient & 10 & \\
\hline$h_{\text {int }, \text { water }}$ & Water convective coefficient & $1.68 \times 10^{3}$ & \\
\hline$R_{\text {air }}$ & $\begin{array}{l}\text { Thermal resistance in the air gap between the two PVC } \\
\text { membranes of gasometric dome }\end{array}$ & 0.13 & $\left(\mathrm{~m}^{2} \mathrm{~K}\right) / \mathrm{W}$ \\
\hline
\end{tabular}

The inlet parameters of the developed model are summarized in Table 7. Note that the specific heat of the digestate is assumed equal to water one at $40{ }^{\circ} \mathrm{C}$. As regards the estimation of gaseous flow rates, the fixed biogas composition is $65 \% \mathrm{CH}_{4}$ and $35 \% \mathrm{CO}_{2}$, according to the range of values reported in literature [37-39]. The hydrogen gas flow rate was neglected due to its very small concentration. The simplified assumption related to the composition of the biogas mixture, $65 \%$ of $\mathrm{CH}_{4}$ and $35 \%$ of $\mathrm{CO}_{2}$ and $\mathrm{CO}_{2}$ production is due to the following reasons: i) it is extremely difficult to implement a detailed calculation of solid/gas transfer for the $\mathrm{CO}_{2}$ production; ii) the main aim of the carried out analysis is the evaluation of the methane production, since this component is the only one affecting the energy balances. However, it can be observed that as $\mathrm{CH}_{4}$ percentage increases, the biogas mass flow rate decreases and the biogas specific heat increases. This globally results in a negligible decrease of digester operating temperature, passing from 38.11 to $37.32{ }^{\circ} \mathrm{C}$ when $\mathrm{CH}_{4}$ percentage increases from $50 \%$ to $70 \%$. The specific heat of the biogas mixture, taking into account the specific heat of each component, i.e., $35.844 \mathrm{~kJ} / \mathrm{kmol} \mathrm{K}$ for $\mathrm{CH}_{4}$ and $37.748 \mathrm{~kJ} / \mathrm{kmol} \mathrm{K}$ for $\mathrm{CO}_{2}$ and the molecular weight of the mixture, assumed equal to $26 \mathrm{~kg} / \mathrm{kmol}$, is equal to $1.42 \mathrm{~kJ} / \mathrm{kgK}$.

Table 7. Inlet parameters of the developed model.

\begin{tabular}{cccc}
\hline Parameter & Description & Value & Unit \\
\hline$\dot{m}_{\text {OFMSW }}$ & Inlet mass flow rate of organic fraction of municipal solid wastes & 15 & $\mathrm{t} / \mathrm{d}$ \\
\hline$\rho_{\text {OFMSW }}$ & Density of organic fraction of municipal solid wastes & 750 & $\mathrm{~kg} / \mathrm{m}^{3}$ \\
\hline$H R T$ & Hydraulic Retention Time & 30 & $\mathrm{~d}$ \\
\hline$T_{\text {setpoint }}$ & Set point temperature of digester & 40 & ${ }^{\circ} \mathrm{C}$ \\
\hline$X_{c, \text { in }}$ & Initial concentration of the complex organic substance & 300 & $\mathrm{kgCOD} / \mathrm{m}^{3}$ \\
\hline$X_{\text {acid }}-X_{\text {acet }}-X_{\text {metaAC }}-X_{\text {metaH2 }}$ & Initial concentration of the microbial families & 0.001 & $\mathrm{kgCOD} / \mathrm{m}^{3}$ \\
\hline
\end{tabular}


Table 7. Cont.

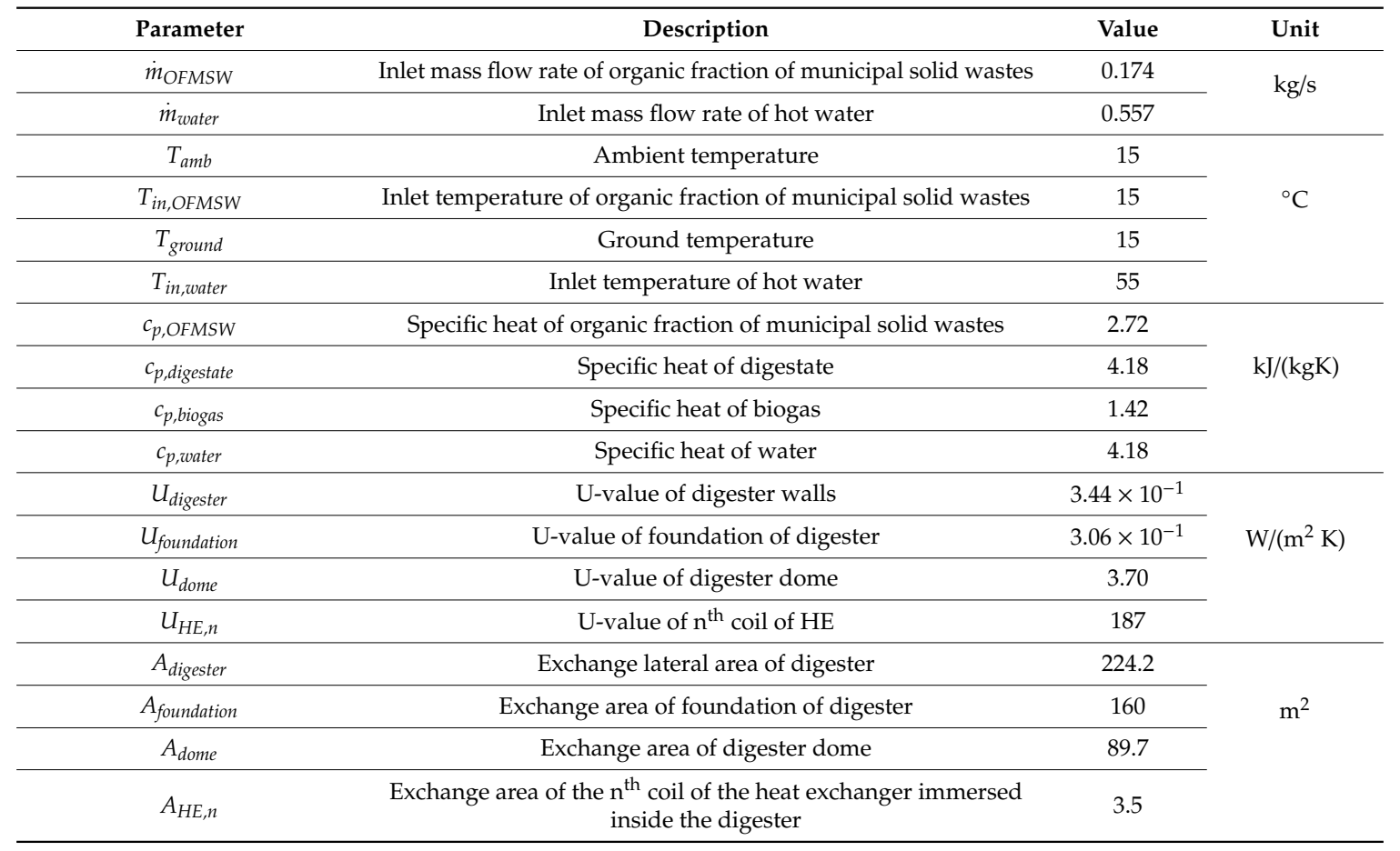

\section{Results and Discussion}

In the hydrolysis phase (Figure 2a), the simple substance, obtained in the disintegration phase, subsequently decomposes, with the consequent production of soluble compounds that rapidly disappear in the acidogenesis phase. The production of the soluble substance leads to the growth of acidogenic biomass and the formation of organic acids. The trend of the concentration of organic acids shows a slope variation due to the gradual disappearance of the soluble substrate, causing a slowdown of the growth of biomass (Figure 2b). During the acetogenesis phase, organic acids are consumed by acetogenic biomass, with the production of acetate and hydrogen. Hydrogen rapidly disappears due to the high rate of degradation of the hydrogenotrophic methanogenic biomass (Figure 2c). The trend of methane concentration shows a first increase due to the rapid degradation of hydrogen and a second increase due to the degradation of acetate (Figure 2d). Figure 3 shows the trend of the volumetric gas flow rates, $\dot{V}_{\text {biogas }}, \dot{V}_{\mathrm{CO}_{2}}$ and $\dot{V}_{\mathrm{CH}_{4}}$ for an operating temperature of $40^{\circ} \mathrm{C}$. As mentioned in the biological model section, the trend of gas flow rates follows the same trend of $S_{\mathrm{CH} 4}$, Figure $2 \mathrm{~d}$. The duration of the initial transient is about 26 days; subsequently, the produced flow rates reach steady values. The obtained concentrations of the analyzed components after 60 days of operation are reported in Table 8. The produced biogas mass flow rate is equal to $2299 \mathrm{~kg} / \mathrm{d}$, composed by $40 \% \mathrm{CH}_{4}(927 \mathrm{~kg} / \mathrm{d})$. The volumetric biogas flow rate results of $1997 \mathrm{Nm}^{3} / \mathrm{d}$, composed by $1298 \mathrm{Nm}^{3} / \mathrm{d}$ of methane and 699 $\mathrm{Nm}^{3} / \mathrm{d}$ of carbon dioxide, (Figure 3). 

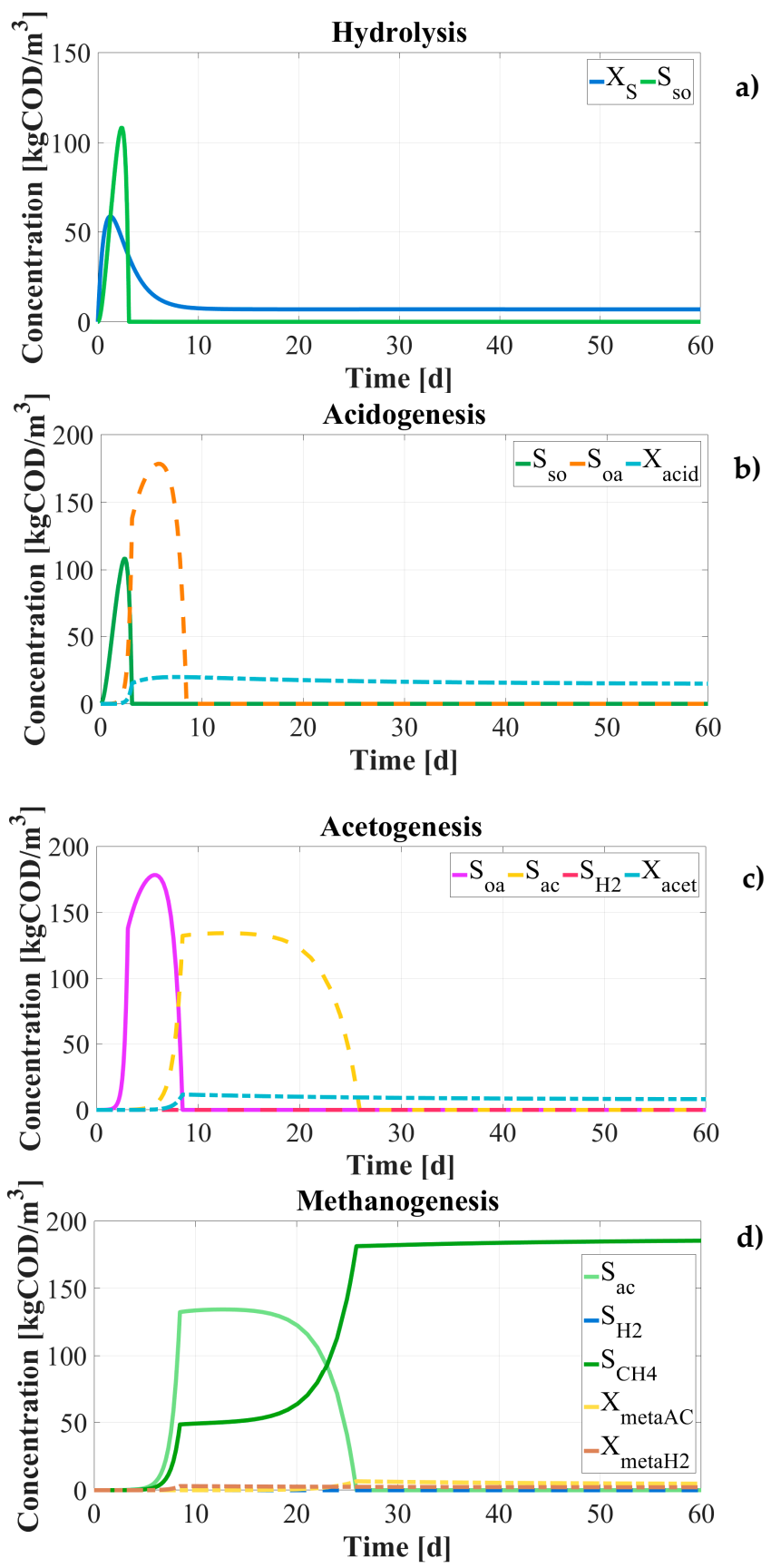

Figure 2. (a) Hydrolysis; (b) acidogenesis; (c) methanogenesis; (d) acetogenesis.

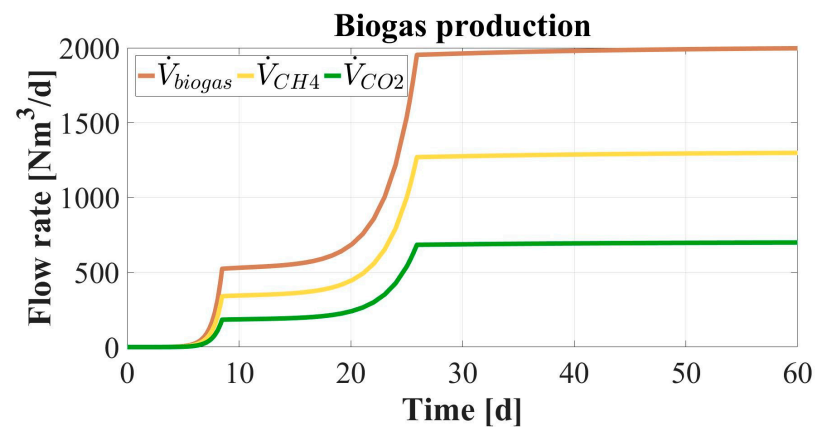

Figure 3. Flow rate of biogas, $\mathrm{CO}_{2}$ and $\mathrm{CH}_{4}$. 
Table 8. Components concentrations under steady-state conditions, after 60 days.

\begin{tabular}{c|ccc}
\hline Parameter & Concentration $\left.\mathbf{( k g C O D} / \mathbf{m}^{3}\right)$ & Parameter & Concentration $\left.\mathbf{( k g C O D} / \mathbf{m}^{3}\right)$ \\
\hline$\left.X_{c}\right)$ & 18.1 & $S_{H 2}$ & $1.59 \times 10^{-7}$ \\
\hline$X_{S}$ & 6.93 & $S_{C H 4}$ & 185 \\
\hline$X_{I}$ & 14.9 & $X_{a c i d}$ & 15.0 \\
\hline$S_{I}$ & 44.7 & $X_{a c e t}$ & 8.13 \\
\hline$S_{s o}$ & $7.97 \times 10^{-3}$ & $X_{\text {metaAC }}$ & 4.79 \\
\hline$S_{o a}$ & $8.10 \times 10^{-3}$ & $X_{\text {metaH2 }}$ & 2.14 \\
\hline$S_{a c}$ & $1.89 \times 10^{-3}$ & & \\
\hline
\end{tabular}

Combining the thermal and biological model, the digester operating temperature, as a function of the heating capacity of the heat exchanger immersed inside the digester, is obtained. By implementing an iterative process and fixing the inlet mass flow rate $\dot{m}_{\text {water }}$ of hot water circulating inside the immersed heat exchanger equal to $0.557 \mathrm{~kg} / \mathrm{s}$, with the corresponding temperature $T_{\text {in, water }}$ at $55^{\circ} \mathrm{C}$, the ambient temperature $T_{a m b}$ at $15^{\circ} \mathrm{C}$ and the inlet mass flow rate of organic fraction of municipal solid wastes $\dot{m}_{O F M S W}$ of $0.174 \mathrm{~kg} / \mathrm{s}$, the results obtained by the developed model are as follows (Table 9):

Table 9. Results.

\begin{tabular}{c|c|c|c|c|c|c}
\hline$T_{\text {digester }}$ & $\boldsymbol{T}_{\text {out }, \text { water }}$ & $\dot{m}_{\text {biogas }}$ & $\dot{Q}_{\text {OFMSW }}$ & $\dot{Q}_{\text {loss }}$ & $\dot{Q}_{\text {water }}$ & $U_{H E, n}$ \\
\hline$\left({ }^{\circ} \mathrm{C}\right)$ & $\left({ }^{\circ} \mathrm{C}\right)$ & $(\mathrm{kg} / \mathrm{h})$ & \multicolumn{3}{|c|}{$(\mathrm{kW})$} & $\left(\mathrm{W} / \mathrm{m}^{2} \mathrm{~K}\right)$ \\
\hline 37.47 & 43.11 & 95.54 & 17.38 & 10.29 & 27.67 & 187 \\
\hline
\end{tabular}

A sensitivity analysis is performed in order to detect the most significant parameters of the model affecting on the biogas production. The alternatively variated parameters are: $\dot{m}_{\text {water }}$ from $0.4 \mathrm{~kg} / \mathrm{s}$ to $0.7 \mathrm{~kg} / \mathrm{s}, T_{\text {in, water }}$ from 49 to $61{ }^{\circ} \mathrm{C}, \dot{m}_{O F M S W}$ from $0.15 \mathrm{~kg} / \mathrm{s}$ to $0.21 \mathrm{~kg} / \mathrm{s}$ and $T_{\text {amb }}$ from -2 to $38^{\circ} \mathrm{C}$. The analyzed outputs of the model are: the digester temperature $T_{\text {digester }}$, outlet temperature of the hot water $T_{\text {out,water }}$, biogas mass flow rate $\dot{m}_{\text {biogas }}$, thermal flow rate absorbed by the mass flow rate of OFMSW $\dot{Q}_{O F M S W}$, thermal flow rate loss of the digester $\dot{Q}_{\text {loss }}$ and thermal flow rate of the hot water $\dot{Q}_{\text {water }}$.

In Figure 4 , the effects of the variation of $\dot{m}_{w a t e r}$ are reported. Obviously, the higher the $\dot{m}_{\text {water, }}$, the higher the $\dot{Q}_{\text {water }}$, i.e. the thermal flow rate exchanged by the water, and as a consequence, an increase of the thermal flow rate absorbed by the OFMSW is detected. This leads to an increase of the operating temperature of the digester $T_{\text {digester, }}$ and therefore, of the produced biogas $\dot{m}_{\text {biogas }}$. Note that the growth of the operating temperature also leads to an increase of heat losses, due to the higher temperature difference between the digester and ambient. The thermal flow rate exchanged by the inlet hot water increases. In fact, considering that $\dot{m}_{\text {water }}$ increases, being fixed the area of the internal heat exchanger, the water velocity inside the tube increases: this determines the intensification of the thermal flow rate by convection, and in turns, an increase of the internal convective coefficient and consequently, of the heat exchange coefficient $U_{H E, n}$ of heat exchanger. For values of $\dot{m}_{\text {water }}$ higher than $0.6 \mathrm{~kg} / \mathrm{s}$, a stable value of $\dot{Q}_{\text {water }}$ is obtained. This means that an increase of $\dot{m}_{\text {water }}$ does not lead to a significant increase of the thermal flow rate exchanged by the water, because the exchange area available of the immersed heat exchanger remains constant. For the same reason, with the same inlet temperature $T_{i n, w a t e r}=55^{\circ} \mathrm{C}$, if the flow rate $\dot{m}_{\text {water }}$ increases, the outlet temperature of the hot water $T_{\text {out,water }}$ increases too. Finally, it is possible to assess that the increase of $\dot{m}_{\text {water }}$ leads only to an increase of the energy consumption of the circulation pumps not determining any significant positive effect in terms of operating temperature of the digester and biogas production. In fact, for an increase of $\dot{m}_{\text {water }}$ from the design value of $0.557 \mathrm{~kg} / \mathrm{s}$ to $0.7 \mathrm{~kg} / \mathrm{s}, T_{\text {digester }}$ increases only from 37 to $39^{\circ} \mathrm{C}$ and a negligible increase of $\dot{m}_{\text {biogas }}$, equal to $0.2 \%$, is obtained. 

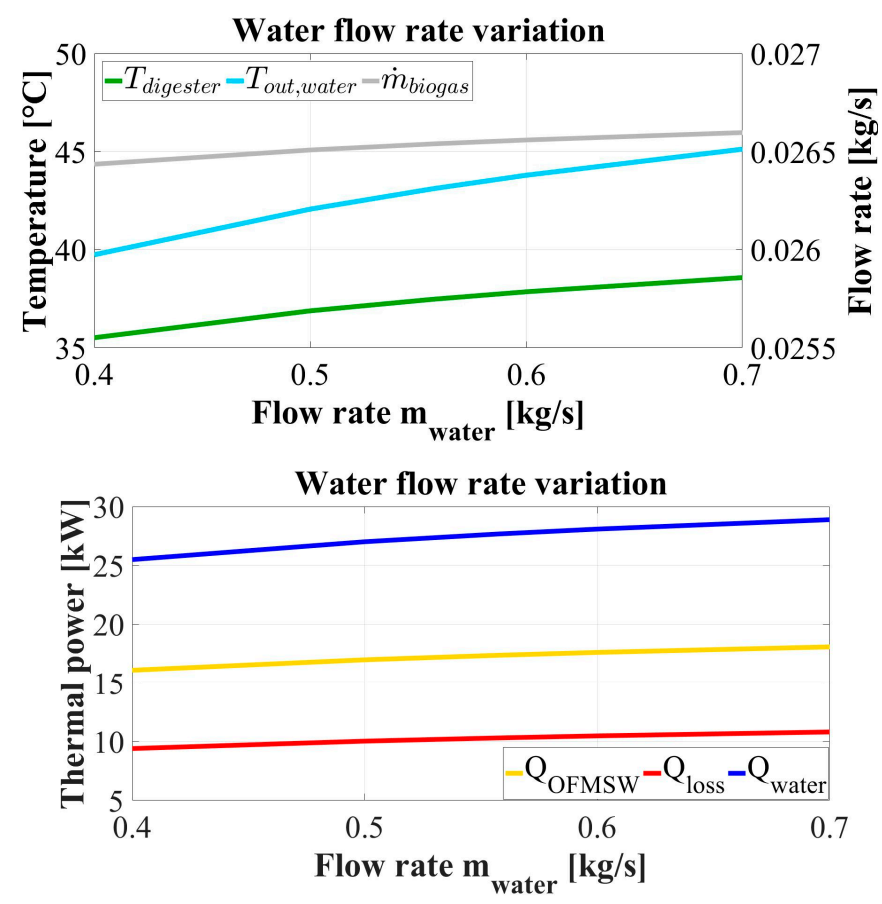

Figure 4. $T_{\text {digester }}, T_{\text {out,water }}, \dot{m}_{\text {biogas }}$ (above) and thermal flow rates $\dot{Q}_{O F M S W}, \dot{Q}_{\text {loss }}, \dot{Q}_{\text {water }}$ (below) vs. $\dot{m}_{\text {water }}$ for $\dot{m}_{O F M S W}=0.174 \mathrm{~kg} / \mathrm{s}, T_{\text {in, water }}=55^{\circ} \mathrm{C}$ and $T_{a m b}=15^{\circ} \mathrm{C}$.

The analysis of the variation of $T_{\text {in,water }}$ is reported in Figure 5 . For higher values of $T_{\text {in,water }}$, all investigated parameters vary according to a growing linear trend. This is easily understood, because higher values of $T_{\text {in,water }}$ correspond to higher exchanged thermal flow rates, $\dot{Q}_{\text {water }}$. However, the increase of operating temperature $T_{\text {digester }}$ also leads to a negative increase of the loss thermal flow rate, $\dot{Q}_{\text {loss }}$. The increase of the inlet water temperature $T_{\text {in,water }}$ with respect to the design value, with the same water flow rate, leads to a potential increase of the thermal flow rate provided to the digester $\dot{Q}_{\text {water }}$. If $\dot{Q}_{\text {water }}$ is produced by a natural gas fired boiler, a grater yearly fuel consumption is detected corresponding to higher operating costs. The high operating costs could be not balanced by an important increase of the biogas production, rising only by $0.7 \%$ in case of $T_{i n, w a t e r}$ is equal to $61^{\circ} \mathrm{C}$.

In Figure 6, the results of the sensitivity analysis performed by changing the inlet mass flow rate of organic fraction of municipal solid wastes $\dot{m}_{O F M S W}$ is presented. In this analysis, the capacity of the digester and of its immersed heat exchanger is tested for different values of $\dot{m}_{O F M S W}$ with respect to the designed one, equal to $0.174 \mathrm{~kg} / \mathrm{s}$. The higher the inlet mass flow rate $\dot{m}_{O F M S W}$, the higher the thermal flow rate transferred by the hot $\dot{Q}_{\text {water }}$. Therefore, at the same inlet temperature of $55^{\circ} \mathrm{C}$, the outlet hot water temperature of the heating system $T_{\text {out,water }}$ decreases with the increase of $\dot{m}_{\text {OFMSW }}$. Obviously, for a greater amount of waste to be treated, a higher thermal flow rate $\dot{Q}_{O F M S W}$ absorbed by the waste and a lower digester operating temperature $T_{\text {digester }}$ is obtained. As a consequence, the thermal losses $\dot{Q}_{\text {loss }}$ decrease. A greater amount of the available waste for anaerobic degradation leads to an increase of the produced mass flow rate of biogas $\dot{m}_{\text {biogas }}$. The final aim of this analysis is to detect the amount of biogas produced corresponding to the possible different inlet OFMSW flow rates $\dot{m}_{O F M S W}$ to the plant. However, the AD process must work at constant operating conditions. Therefore, only slight variations of $\dot{m}_{O F M S W}$ can be accepted. The analysis shows that for each $\mathrm{kg}$ of OFMSW $0.132 \mathrm{Nm}^{3}$ of biogas are produced. 

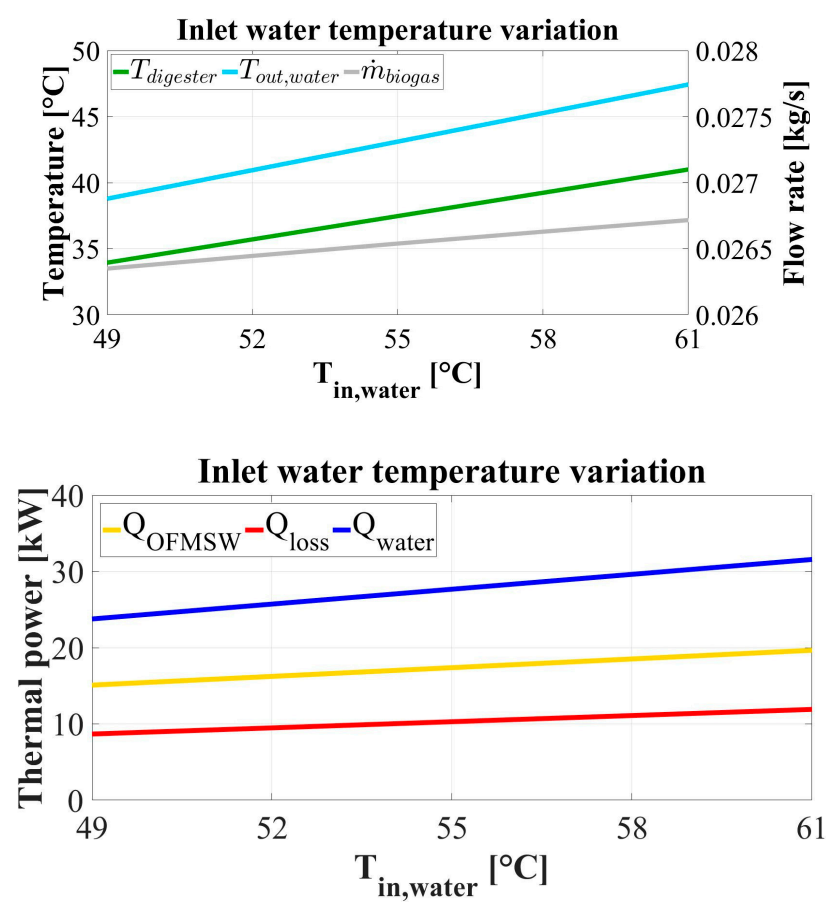

Figure 5. $T_{\text {digester }}, T_{\text {out,water, }} \dot{m}_{\text {biogas }}$ (above) and thermal flow rates $\dot{Q}_{O F M S W}, \dot{Q}_{\text {loss }}, \dot{Q}_{\text {water }}$ (below) vs. $T_{\text {in,water }}$ for $\dot{m}_{\text {OFMSW }}=0.174 \mathrm{~kg} / \mathrm{s}, \dot{m}_{\text {water }}=0.557 \mathrm{~kg} / \mathrm{s}$ and $T_{\text {amb }}=15^{\circ} \mathrm{C}$.
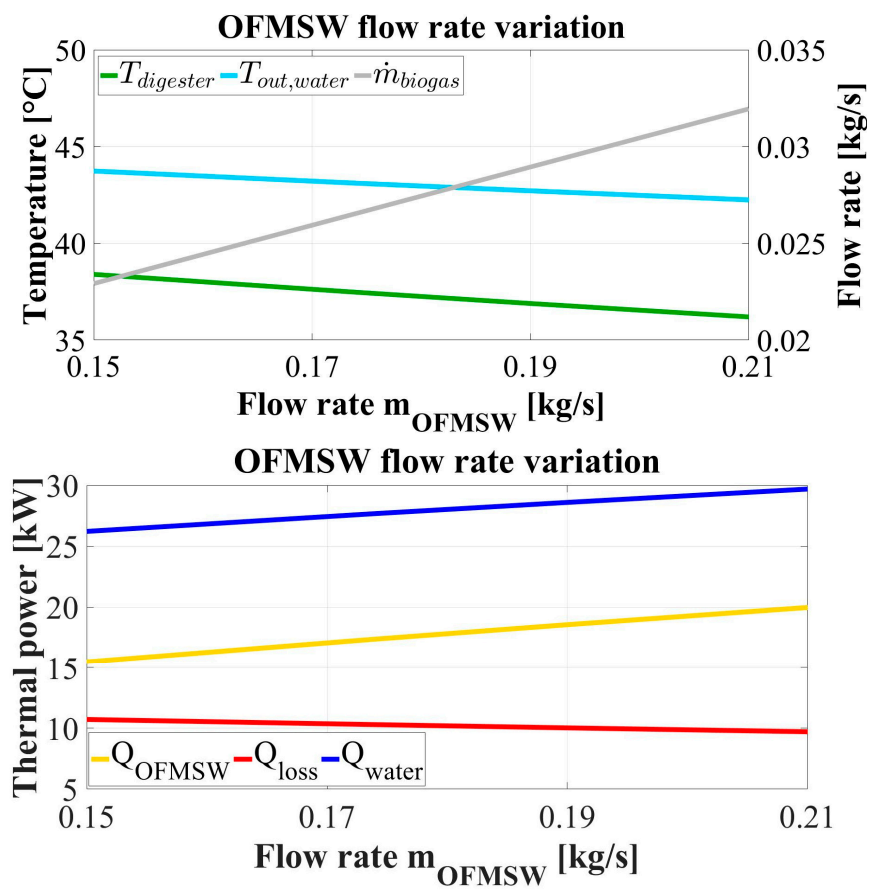

Figure 6. $T_{\text {digester }}, T_{\text {out,water, }} \dot{m}_{\text {biogas }}$ (above) and thermal flow rates $\dot{Q}_{O F M S W}, \dot{Q}_{\text {loss }}, \dot{Q}_{\text {water }}$ (below) vs. $\dot{m}_{O F M S W}$ for $\dot{m}_{\text {water }}=0.557 \mathrm{~kg} / \mathrm{s}, T_{\text {in,water }}=55^{\circ} \mathrm{C}$ and $T_{a m b}=15^{\circ} \mathrm{C}$.

The sensitivity analysis is performed by varying the ambient temperature $T_{a m b}$ (Figure 7 ), in order to investigate the biogas production as a function of the weather conditions. Note that for the model assumption, the waste temperature is equal to $T_{a m b}$. Therefore, for higher values of $T_{a m b}$, the heat absorbed by the waste decreases as well as $T_{\text {out,water }}$ increases. For hot weather zones, the thermal losses decrease, therefore, the available heat for the waste increases. This leads to higher digester operating temperatures, therefore, greater biogas flow rates produced. By comparing the results obtained from 
this analysis it is possible to observe that among the varied parameters, i.e., $T_{a m b}, \dot{m}_{O F M S W}, \dot{m}_{w a t e r}$, $T_{\text {in,water }}$ the main parameter of the model is the ambient temperature $T_{a m b}$. In fact, the variation from -2 to $38{ }^{\circ} \mathrm{C}$ leads to a very significant variation of the operating temperature, from 32 to $45{ }^{\circ} \mathrm{C}$. $T_{a m b}$ is a crucial parameter, dramatically affecting the biological process. Therefore, it also affects the velocity and efficiency of the process. For this reason, in cold weather zones, it is more difficult to achieve suitable operating conditions for the anaerobic digestion. This problem could significantly increase the energy consumption of the plant as well as the yearly operating costs. For the same reason, it is important to control the operating temperature of digester also during winter season when the ambient temperature dramatically decreases also in mild climates.
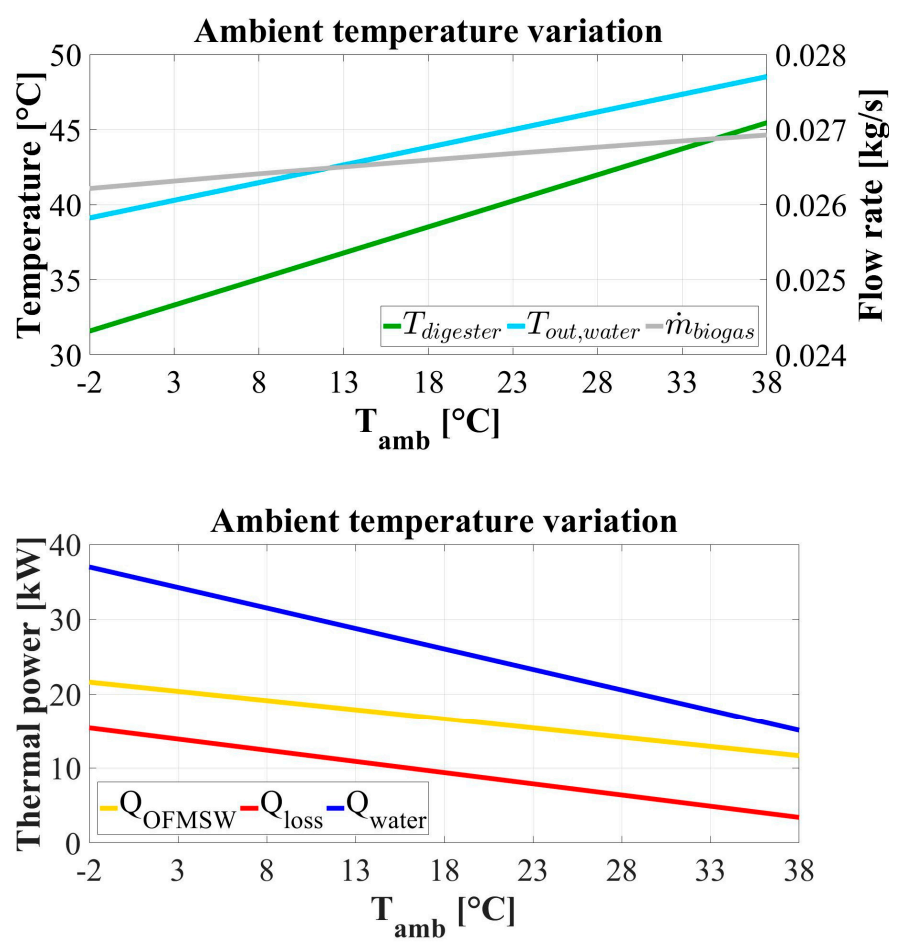

Figure 7. $T_{\text {digester }}, T_{\text {out,water }} \dot{m}_{\text {biogas }}$ (above) and thermal flow rates $\dot{Q}_{O F M S W}, \dot{Q}_{\text {loss }}, \dot{Q}_{\text {water }}$ (below) vs. $T_{\text {amb }}$ for $\dot{m}_{O F M S W}=0.174 \mathrm{~kg} / \mathrm{s}, \dot{m}_{\text {water }}=0.557 \mathrm{~kg} / \mathrm{s}$ and $T_{\text {in,water }}=55^{\circ} \mathrm{C}$.

\subsection{Sensitivity Analysis: Digester Wall Insulation Thickness}

In this paper, a specific wall of the digester was considered. However, from the technical point of view several options are available. Therefore, in order to analyze the effects of digester wall features on the system performance a sensitivity analysis is also performed by varying the global transmittance values of digester walls. When the insulation thickness increases assuming values from 0.05 to $0.35 \mathrm{~m}$, $U_{\text {digester }}$ reduces in the range $0.102-0.644 \mathrm{~W} /\left(\mathrm{m}^{2} \mathrm{~K}\right)$. This results in a slightly improvement of system performances: the digester operating temperature and the methane flow rate increase by about $1^{\circ} \mathrm{C}$ and $3 \mathrm{Nm}^{3} / \mathrm{d}$, respectively (Figure 8). As $T_{\text {digester }}$ increases, the thermal power required to heat the OFMSW also increases, however the losses decrease due to the better system insulation, so the overall thermal power exchanged by the heating system decreases (Figure 9). Note that thermal losses along digester walls account for $11 \%$ of total losses, mainly caused by gasometric dome, so even increasing the insulation thickness, no significant increase in digester temperature is observed. Details of the results obtained by this analysis are summarized in Table 10. 


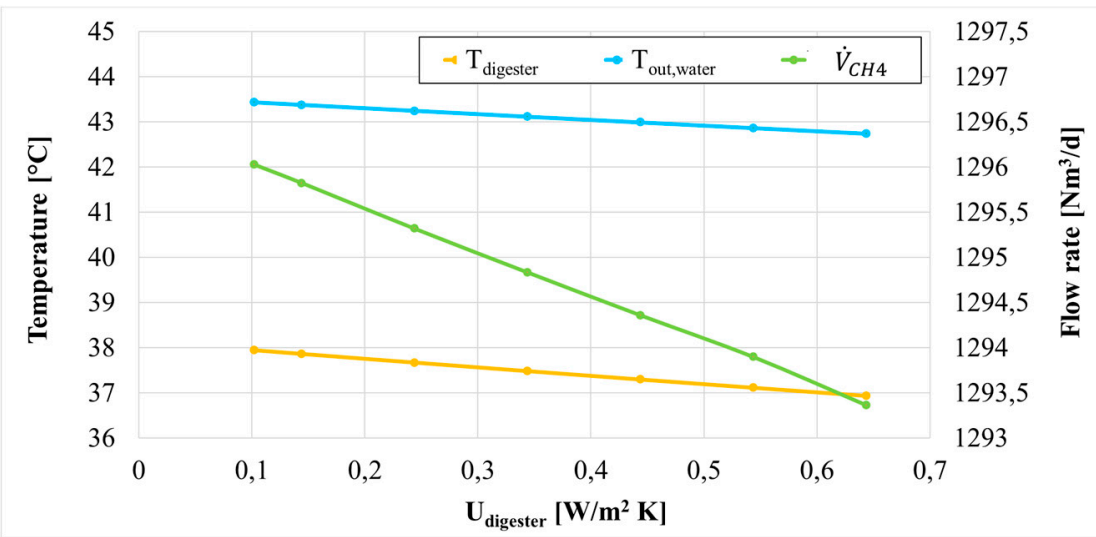

Figure 8. $T_{\text {digester }}, T_{\text {out,water }}, \dot{V}_{C H 4}$ vs. $U_{\text {digester }}$ for $\dot{m}_{O F M S W}=0.174 \mathrm{~kg} / \mathrm{s}, \dot{m}_{\text {water }}=0.557 \mathrm{~kg} / \mathrm{s}$ and $T_{\text {in,water }}$ $=55^{\circ} \mathrm{C}$.

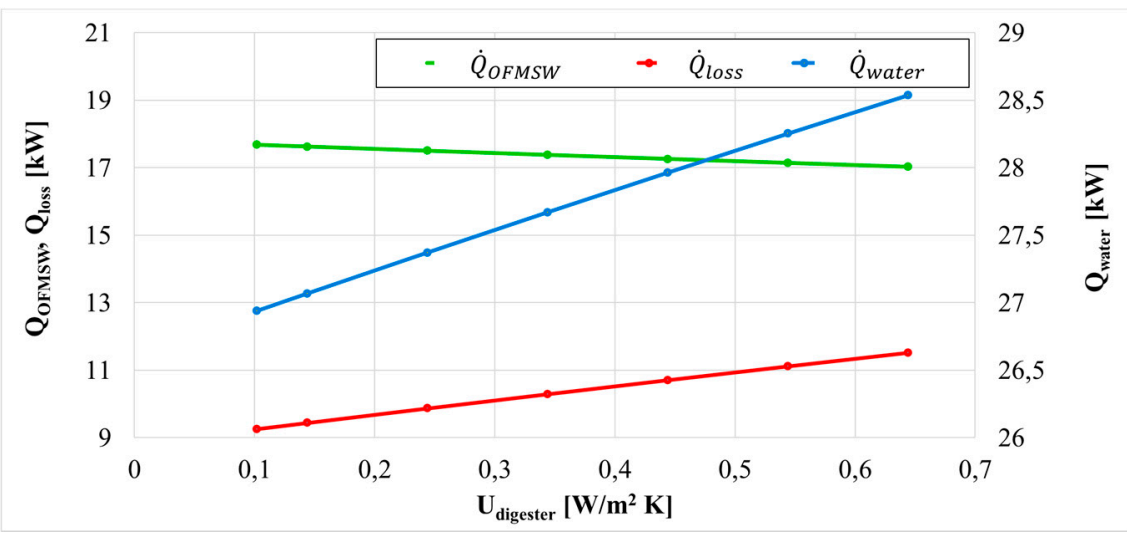

Figure 9. Thermal flow rates $\dot{Q}_{O F M S W}, \dot{Q}_{\text {loss }}, \dot{Q}_{\text {water }}$ vs. $U_{\text {digester }}$ for $\dot{m}_{O F M S W}=0.174 \mathrm{~kg} / \mathrm{s}$, $\dot{m}_{\text {water }}=0.557 \mathrm{~kg} / \mathrm{s}$ and $T_{\text {in, water }}=55^{\circ} \mathrm{C}$.

Table 10. Variation in model results due by varying walls' insulation thickness.

\begin{tabular}{cccccccc}
\hline$s_{X P S-S L, w}(\mathbf{m})$ & 0.05 & 0.06 & 0.08 & 0.10 & 0.14 & 0.25 & 0.35 \\
\hline$U_{\text {digester }}\left(\mathbf{W} / \mathbf{m}^{2} \mathbf{K}\right)$ & 0.644 & 0.544 & 0.444 & 0.344 & 0.244 & 0.144 & 0.102 \\
\hline$\dot{V}_{\text {biogas }}\left(\mathbf{N m}^{3} / \mathbf{d}\right)$ & 1990 & 1991 & 1991 & 1992 & 1993 & 1994 & 1994 \\
\hline$\dot{V}_{\text {CH4 }}\left(\mathbf{N m}^{3} / \mathbf{d}\right)$ & 1293 & 1294 & 1294 & 1295 & 1295 & 1296 & 1296 \\
\hline$\dot{m}_{\text {biogas }}(\mathbf{k g} / \mathrm{d})$ & 2290 & 2291 & 2292 & 2293 & 2294 & 2295 & 2295 \\
\hline$\dot{m}_{\text {CH4 }}(\mathbf{k g} / \mathbf{d})$ & 923 & 924 & 924 & 924 & 925 & 925 & 925 \\
\hline$T_{\text {digester }}\left({ }^{\circ} \mathbf{C}\right)$ & 37 & 37 & 37 & 37 & 38 & 38 & 38 \\
\hline$T_{\text {out }, \text { water }}\left({ }^{\circ} \mathbf{C}\right)$ & 43 & 43 & 43 & 43 & 43 & 43 & 43 \\
\hline$\dot{Q}_{\text {OFMSW }}(\mathbf{k W})$ & 17 & 17 & 17 & 17 & 18 & 18 & 18 \\
\hline$\dot{Q}_{\text {loss }}(\mathbf{k W})$ & 12 & 11 & 11 & 10 & 10 & 9 & 9 \\
\hline$\dot{Q}_{\text {water }}(\mathbf{k W})$ & 29 & 28 & 28 & 28 & 27 & 27 & 27 \\
\hline
\end{tabular}

Figure 10 shows the variation in biogas production and operating temperature by varying insulation thickness and therefore the walls' transmittance. An increase of SXPS-XL,w until $20 \mathrm{~cm}$ results in a rapid improvement of system performances; after this value the parameters begin almost constant, so increasing insulation thickness results unnecessary and expensive. 


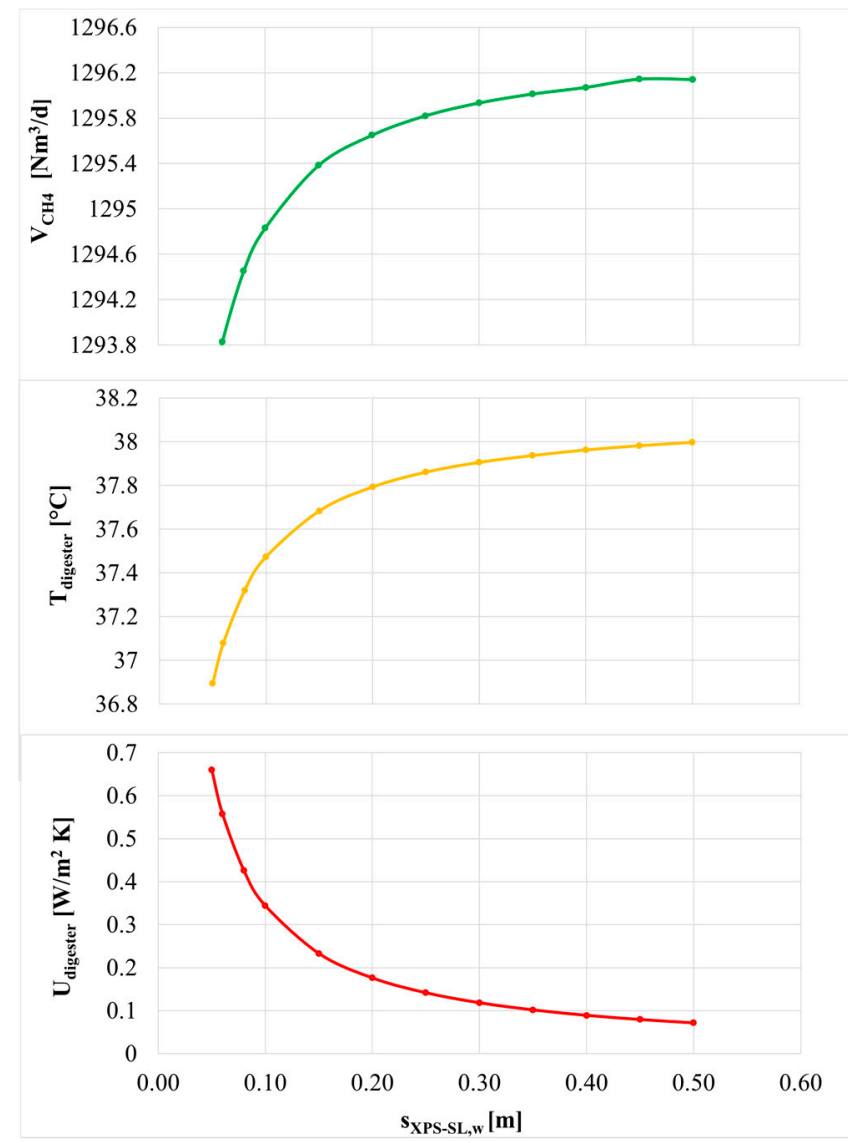

Figure 10. Influence of insulation thickness on $U_{\text {digester }}$ value, operating temperature and biogas production.

\subsection{Sensitivity Analysis: Effect of Fouling in the Internal and External Side of the Heat Exchanger}

In this paper the effect of fouling in the internal side of the heat exchanger was neglected since only pre-treated water is used in this kind of systems and fouling will be a very limited phenomenon. Thus, a sensitivity analysis by considering the synergistic effect of an internal and external fouling on $U_{H E, n}$ value is carried out. Results of this analysis is represented in Figures 11 and 12 and Table 11.

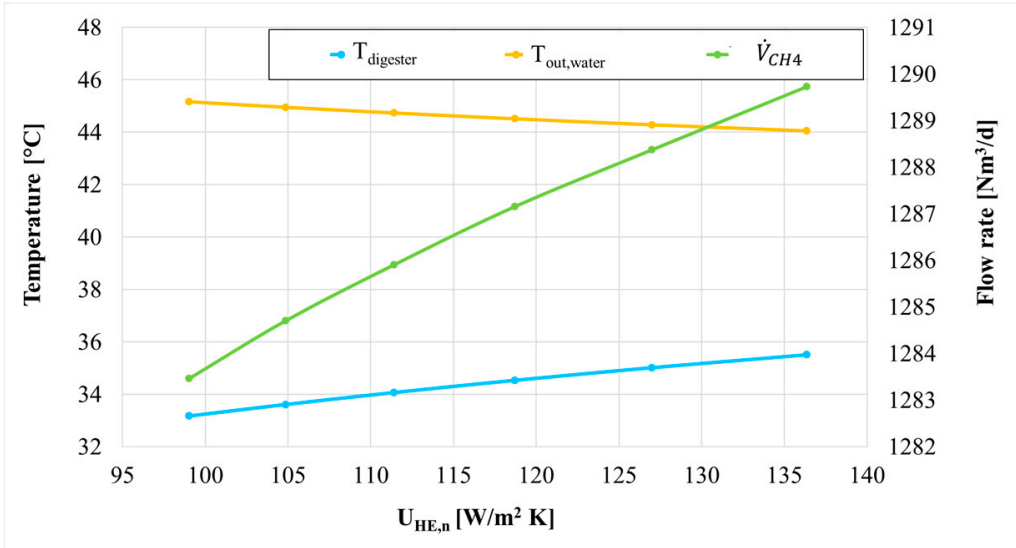

Figure 11. $T_{\text {digester }}, T_{\text {out }, \text { water }}, \dot{V}_{C H 4}$ vs. $U_{H, n}$ for $\dot{m}_{O F M S W}=0.174 \mathrm{~kg} / \mathrm{s}, \dot{m}_{\text {water }}=0.557 \mathrm{~kg} / \mathrm{s}$ and $T_{\text {in, water }}=$ $55^{\circ} \mathrm{C}$. 


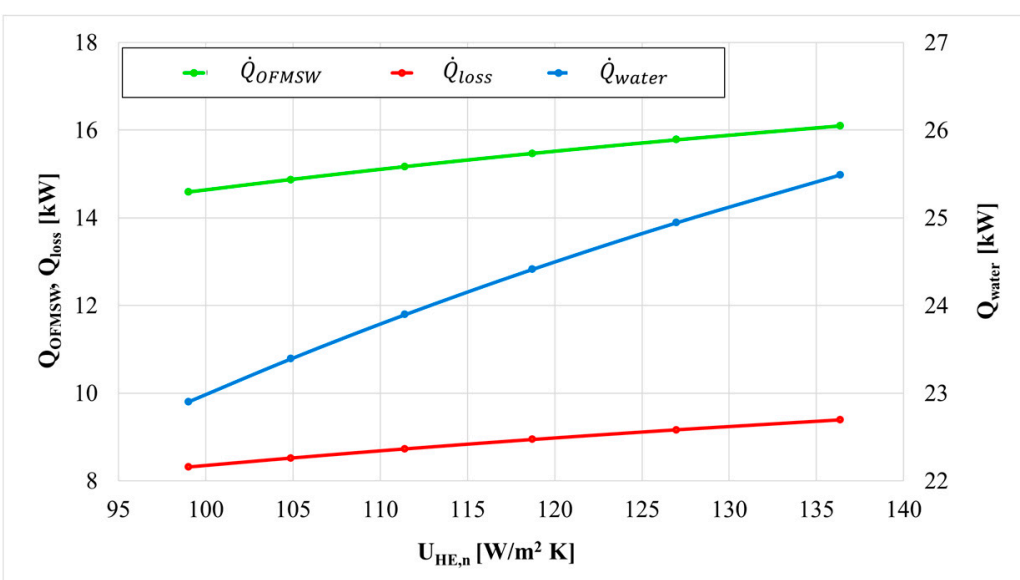

Figure 12. Thermal flow rates $\dot{Q}_{O F M S W}, \dot{Q}_{\text {loss }}, \dot{Q}_{w a t e r}$ vs. $U_{H E, n}$ for $\dot{m}_{O F M S W}=0.174 \mathrm{~kg} / \mathrm{s}$, $\dot{m}_{\text {water }}=0.557 \mathrm{~kg} / \mathrm{s}$ and $T_{\text {in,water }}=55^{\circ} \mathrm{C}$.

Table 11. Variation in model results due to internal and external fouling.

\begin{tabular}{cccccccc}
\hline$s_{\text {fouling }}(\mathbf{m})$ & 0 & 0 & $1 \times 10^{-3}$ & $2 \times 10^{-3}$ & $3 \times 10^{-3}$ & $4 \times 10^{-3}$ & $5 \times 10^{-3}$ \\
\hline$R_{\text {fouling, est }}\left(\mathbf{m}^{\mathbf{2}} \mathbf{K} / \mathbf{W}\right)$ & 0 & $2 \times 10^{-3}$ & $2 \times 10^{-3}$ & $2 \times 10^{-3}$ & $2 \times 10^{-3}$ & $2 \times 10^{-3}$ & $2 \times 10^{-3}$ \\
\hline$U_{\text {HE, } n}\left(\mathbf{W} / \mathbf{m}^{\mathbf{2}} \mathbf{K}\right)$ & 187 & 136 & 127 & 119 & 111 & 105 & 99 \\
\hline$\dot{V}_{\text {biogas }}\left(\mathbf{N m}^{3} / \mathbf{d}\right)$ & 1992 & 1984 & 1982 & 1980 & 1978 & 1976 & 1975 \\
\hline$\dot{V}_{\text {CH4 }}\left(\mathbf{N m}^{3} / \mathbf{d}\right)$ & 1295 & 1290 & 1288 & 1287 & 1286 & 1285 & 1283 \\
\hline$\dot{m}_{\text {biogas }}(\mathbf{k g} / \mathbf{d})$ & 2293 & 2284 & 2282 & 2279 & 2277 & 2275 & 2273 \\
\hline$\dot{m}_{\text {CH4 }}(\mathbf{k g} / \mathbf{d})$ & 924 & 921 & 920 & 919 & 918 & 917 & 916 \\
\hline$T_{\text {digester }}\left({ }^{\circ} \mathbf{C}\right)$ & 37 & 36 & 35 & 35 & 34 & 34 & 33 \\
\hline$T_{\text {out }, \text { water }}\left({ }^{\circ} \mathbf{C}\right)$ & 43 & 44 & 44 & 45 & 45 & 45 & 45 \\
\hline$\dot{Q}_{\text {OFMSW }}(\mathbf{k W})$ & 17 & 16 & 16 & 15 & 15 & 15 & 15 \\
\hline$\dot{Q}_{\text {loss }}(\mathbf{k W})$ & 10 & 9 & 9 & 9 & 9 & 9 & 8 \\
\hline$\dot{Q}_{\text {water }}(\mathbf{k W})$ & 28 & 25 & 25 & 24 & 24 & 23 & 23 \\
\hline
\end{tabular}

The internal fouling is caused by precipitation of impurities in the heat transfer fluid and causes the reduction of the available cross area to water flow. This is modeled replacing a lower value of pipe rated diameter $D N$ in the calculation of $U_{H E, n}$, assuming that fouling occurs along the whole pipe internal surface:

$$
D N_{H E, n-\text { fouling }}=D N_{H E, n}-2 s_{\text {fouling }}
$$

where $s_{\text {fouling }}$ is fouling thickness. Assuming the formation of a limestone fouling varying in thickness from $1 \times 10^{-4}$ to $5 \times 10^{-3} \mathrm{~m}$ with a thermal conductivity $\lambda_{\mathrm{CaCo} 3}=1.6 \mathrm{~W} / \mathrm{m} \mathrm{K}$ and considering an additional thermal resistance $R_{\text {fouling,est }}=2 \times 10^{-3} \mathrm{~m}^{2} \mathrm{~K} / \mathrm{W}$ caused by organic deposits on external side of the heat exchanger pipes, both internal and external fouling are taken into account. It is possible to observe that the global transmittance $U_{H E, n}$ is considerably decreased with respect to the design value $187 \mathrm{~W} /\left(\mathrm{m}^{2} \mathrm{~K}\right)$ and a significant reduction in system performance occurs (Figures 11 and 12 ). External fouling alone results in a reduction of $U_{H E, n}$ from 187 to $136 \mathrm{~W} /\left(\mathrm{m}^{2} \mathrm{~K}\right)$ with a decrease in temperature of about $1{ }^{\circ} \mathrm{C}$ (Table 11). The formation of limestone further reduces $U_{H E, n}$ value and it causes a reduction of operating temperature of about half degree per millimeter of fouling (Figure 11). 


\section{Conclusions}

In this work, a model simulating the biological and thermal processes of the AD of the organic fraction of solid urban waste was developed. The model evaluates the dynamic trend of the concentrations of the main components and estimates the production of biogas according to the operating temperature of the digester, depending on the heat exchange occurring inside the digester between the waste and heating system. The simplified version of the ADM1 is used in order to simply predict the biomethane production. This can be a useful estimation when the developed model will be integrated within a more complex system, including different components: biomethane vehicles, thermal storage tanks, solar thermal collectors, photovoltaic (PV) panels, upgrading unit, etc. The main results can be summarized as follows:

- For a $21 \%$ increase of waste flow rate with respect the design value (from 626 a $756 \mathrm{~kg} / \mathrm{h}$ ), a proportional increase of the biogas flow rate (from 96 to $115 \mathrm{~kg} / \mathrm{h}$ ) is obtained. In this case, a reduction of the operating temperature of about $1{ }^{\circ} \mathrm{C}$ is noted.

- For a $26 \%$ increase of the heating water with respect to designed value (from 2005 to $2520 \mathrm{~kg} / \mathrm{h}$ ), the digester operating temperature increases of about $1{ }^{\circ} \mathrm{C}$ and the produced biogas only of $0.2 \%$ (from 95.54 to $95.75 \mathrm{~kg} / \mathrm{h}$ ).

- When the inlet water temperature varies from 49 to $61^{\circ} \mathrm{C}$, the digester operating temperature ranges in the desired mesophilic regime $\left(34-41^{\circ} \mathrm{C}\right)$ and the produced biogas flow rate varies of about $1.3 \mathrm{~kg} / \mathrm{h}$.

- The increase of the insulation thickness on the wall of the digester leads to a reduction in the digester heat losses, but because the main heat losses of digester are due to the geometric dome, the digester temperature only slightly increases.

- The fouling in the internal side of the heat exchanger could reduce the available cross area to water flow. However, this effect can be neglected when the heat transfer fluid is pre-treated.

- External fouling leads to a reduction of the global transmittance of the heat exchanger and therefore, also of the operating temperature (half degree per millimeter of fouling).

The following general considerations can be made by analysing the obtained results:

- The calculated biogas production is $0.132 \mathrm{Nm}^{3}$ per kg of OFMSW.

- To increase the operating temperature $T_{\text {digester }}$ by $1{ }^{\circ} \mathrm{C}$, inlet hot water temperature Tin, water must be increased by about $1.5^{\circ} \mathrm{C}$, fixing all the remaining parameters.

- A variation of $1{ }^{\circ} \mathrm{C}$ in the environmental temperature Tamb leads to a reduction of about $0.3^{\circ} \mathrm{C}$ in the operating temperature $T_{\text {digester }}$, due to the higher heat losses.

- For a fluctuation of 1 tonne of the OFMSW daily flow rate, the digester operating temperature varies by $0.5^{\circ} \mathrm{C}$, due to the larger amount of heat required to preheat the inlet OFMSW.

With a suitable control system all the main parameters of the model, such as the flow rate and temperature of the heating system, can be appropriately varied in order to maintain the operating temperature of the digester at the design value, if fluctuations in OFMSW flow rate and environmental temperature occur.

The simplified model of the anaerobic digestion is useful for the prediction of the biomethane production, but it is definitely more advantageous if integrated with other simulation models. For example, in order to reduce the contribution of the conventional fossil fuels to meet the energy demand of the digester. In particular, solar thermal collectors could be used to provide the thermal energy of the anaerobic digestion process as well as PV panels to provide the electric energy to the upgrading unit process. In addition, in a wider prospective, the contribution of such systems is definitively positive for the development of a sustainable mobility scenario based on the use of methane vehicles. Future developments of the present model will be oriented to a better characterization of the inlet substrate and to the modeling of physical-chemical reactions and inhibition phenomena that can occur during 
the AD process and that can vary the amount of the produced methane. These improvements will increase the reliability of the model under dynamic operating conditions.

Author Contributions: F.C., F.L.C., M.D.d., A.I. and M.V. contributed equally in this manuscript. All authors have read and agreed to the published version of the manuscript.

Funding: This research received no external funding

Conflicts of Interest: The authors declare no conflict of interest. The corresponding author confirms that all the other authors have read and approved the manuscript and no ethical issues are involved.

\section{Nomenclature}

\begin{tabular}{|c|c|c|c|}
\hline$A$ & Area, $\mathrm{m}^{2}$ & OFMSW & Organic Fraction of Municipal Solid Waste \\
\hline C & $\begin{array}{l}\text { Concentration of a generic component, } \\
\mathrm{kgCOD} / \mathrm{m}^{3}\end{array}$ & $\operatorname{Pr}$ & Prandtl number \\
\hline$c$ & Specific heat, kJ/(kg K) & $\dot{Q}$ & Energy flow, $\mathrm{W}, \mathrm{kW}$ \\
\hline$C O D$ & Chemical oxygen demand & $\widetilde{R}$ & Thermal resistance, $\mathrm{m}^{2} \mathrm{~K} / \mathrm{W}$ \\
\hline$D N$ & Rated diameter, $\mathrm{m}, \mathrm{cm}$ & $\operatorname{Re}$ & Reynolds number \\
\hline$f$ & Yield of product on substrate & $S$ & $\begin{array}{l}\text { Concentration of soluble components, } \\
\mathrm{kgCOD} / \mathrm{m}^{3}\end{array}$ \\
\hline$h$ & Convective heat transfer coefficient, $\mathrm{W} / \mathrm{m}^{2} \mathrm{~K}$ & $s$ & Thickness, $\mathrm{m}, \mathrm{cm}, \mathrm{mm}$ \\
\hline$H E$ & Heat exchanger & $T$ & Temperature, ${ }^{\circ} \mathrm{C}$ \\
\hline Y & Yield of biomass & $t$ & Time, second, hour or day \\
\hline K & Half-saturation constant, $\mathrm{kgCOD} / \mathrm{m}^{3}$ & $T S$ & Total solids \\
\hline$k$ & First order rate, $\mathrm{d}^{-1}$ & $U$ & Global heat transmission coefficient, $\mathrm{W} /\left(\mathrm{m}^{2} \mathrm{~K}\right)$ \\
\hline$L$ & Length, $\mathrm{m}$ & $\dot{V}$ & Volume flow rate, $\mathrm{Nm}^{3} / \mathrm{d}$ \\
\hline$\dot{m}$ & Mass flow rate, $\mathrm{kg} / \mathrm{d}, \mathrm{kg} / \mathrm{h}, \mathrm{kg} / \mathrm{s}$ & $X$ & $\begin{array}{l}\text { Concentration of particulate components and } \\
\text { biomass, } \mathrm{kgCOD} / \mathrm{m}^{3}\end{array}$ \\
\hline$N u$ & Nusselt number & & \\
\hline \multicolumn{4}{|c|}{ Greek symbols } \\
\hline$\alpha$ & Biochemical coefficient & $\rho$ & Density, $\mathrm{kg} / \mathrm{m}^{3}$ \\
\hline$\lambda$ & Thermal conductivity, $\mathrm{W} /(\mathrm{m} \mathrm{K})$ & $\varphi$ & Kinetic equation \\
\hline$\mu$ & Dynamic viscosity, $\mathrm{Pa}^{*} \mathrm{~s}$ & & \\
\hline$v$ & $\begin{array}{l}\text { Michaelis-Menten maximum specific uptake } \\
\text { rate, } \mathrm{d}^{-1}\end{array}$ & & \\
\hline \multicolumn{4}{|c|}{ Subscripts and superscripts } \\
\hline$a c$ & Acetate & metaAC & Aceticlastic methanogenesis \\
\hline acet & Acetogenesis & metaH2 & Hydrogenotropic methanogenesis \\
\hline acid & Acidogenesis & $M G$ & Underground concrete material \\
\hline$a m b$ & Ambient & $n$ & $\mathrm{n}^{\text {th }}$ heat exchanger tube \\
\hline$c$ & Complex & $o a$ & Organic acids \\
\hline$C h$ & Carbohydrates & out & Outlet \\
\hline CLS & Concrete material & $p$ & Constant pressure \\
\hline$d$ & Decay & $P E-X a$ & Peroxidic cross-linked polyethylene \\
\hline dis & Disintegration & $\operatorname{Pr}$ & Proteins \\
\hline est & External side & $P V C$ & Polyvinyl chloride \\
\hline$f$ & About digester foundation & $S$ & Simple \\
\hline$H E$ & Heat exchanger & $s$ & Half-saturation \\
\hline hydro & Hydrolysis & so & Soluble \\
\hline$I$ & Inert & $w$ & About digester walls \\
\hline$i$ & About the component " $i$ " & waste & Component contained in the waste \\
\hline in & Inlet & $X P S-S L$ & Extruded polystyrene insulation \\
\hline int & Internal side & $S T$ & Steel \\
\hline$j$ & About the process " $j$ " & & \\
\hline $\mathrm{Li}$ & Lipids & & \\
\hline $\operatorname{lm}$ & Logarithmic mean & & \\
\hline loss & Thermal losses & & \\
\hline $\max$ & Maximum & & \\
\hline
\end{tabular}




\section{References}

1. Salgot, M.; Folch, M. Wastewater treatment and water reuse. Curr. Opin. Environ. Sci. Health 2018, 2, 64-74. [CrossRef]

2. Filipe, J.; Bessa, R.J.; Reis, M.; Alves, R.; Póvoa, P. Data-driven predictive energy optimization in a wastewater pumping station. Appl. Energy 2019, 252, 113423. [CrossRef]

3. Longo, S.; d'Antoni, B.M.; Bongards, M.; Chaparro, A.; Cronrath, A.; Fatone, F.; Lema, J.M.; Mauricio-Iglesias, M.; Soares, A.; Hospido, A. Monitoring and diagnosis of energy consumption in wastewater treatment plants. A state of the art and proposals for improvement. Appl. Energy 2016, 179, 1251-1268. [CrossRef]

4. Zhang, Z.; Kusiak, A.; Zeng, Y.; Wei, X. Modeling and optimization of a wastewater pumping system with data-mining methods. Appl. Energy 2016, 164, 303-311. [CrossRef]

5. Asadi, A.; Verma, A.; Yang, K.; Mejabi, B. Wastewater treatment aeration process optimization: A data mining approach. J. Environ. Manag. 2017, 203, 630-639. [CrossRef]

6. Guven, H.; Dereli, R.K.; Ozgun, H.; Ersahin, M.E.; Ozturk, I. Towards sustainable and energy efficient municipal wastewater treatment by up-concentration of organics. Prog. Energy Combust. Sci. 2019, 70, 145-168. [CrossRef]

7. Shen, Y.; Linville, J.L.; Urgun-Demirtas, M.; Mintz, M.M.; Snyder, S.W. An overview of biogas production and utilization at full-scale wastewater treatment plants (WWTPs) in the United States: Challenges and opportunities towards energy-neutral WWTPs. Renew. Sustain. Energy Rev. 2015, 50, 346-362. [CrossRef]

8. Wang, J.; You, S.; Zong, Y.; Træholt, C.; Dong, Z.Y.; Zhou, Y. Flexibility of combined heat and power plants: A review of technologies and operation strategies. Appl. Energy 2019, 252, 113445. [CrossRef]

9. Salman, C.A.; Naqvi, M.; Thorin, E.; Yan, J. Impact of retrofitting existing combined heat and power plant with polygeneration of biomethane: A comparative techno-economic analysis of integrating different gasifiers. Energy Convers. Manag. 2017, 152, 250-265. [CrossRef]

10. Picardo, A.; Soltero, V.M.; Peralta, M.E.; Chacartegui, R. District heating based on biogas from wastewater treatment plant. Energy 2019, 180, 649-664. [CrossRef]

11. Patterson, T.; Esteves, S.; Dinsdale, R.; Guwy, A.; Maddy, J. Life cycle assessment of biohydrogen and biomethane production and utilisation as a vehicle fuel. Bioresour. Technol. 2013, 131, 235-245. [CrossRef] [PubMed]

12. Di Fraia, S.; Macaluso, A.; Massarotti, N.; Vanoli, L. Energy, exergy and economic analysis of a novel geothermal energy system for wastewater and sludge treatment. Energy Convers. Manag. 2019, 195, 533-547. [CrossRef]

13. Pasini, G.; Baccioli, A.; Ferrari, L.; Antonelli, M.; Frigo, S.; Desideri, U. Biomethane grid injection or biomethane liquefaction: A technical-economic analysis. Biomass Bioenergy 2019, 127, 105264. [CrossRef]

14. Lillo, P.; Ferrer-Martí, L.; Fernández-Baldor, Á.; Ramírez, B. A new integral management model and evaluation method to enhance sustainability of renewable energy projects for energy and sanitation services. Energy Sustain. Dev. 2015, 29, 1-12. [CrossRef]

15. Campuzano, R.; González-Martínez, S. Characteristics of the organic fraction of municipal solid waste and methane production: A review. Waste Manag. 2016, 54, 3-12. [CrossRef]

16. Cecchi, F.; Pavan, P.; Battistoni, P.; Bolzonella, D.; Innocenti, L. Conference Proceedings. Characteristics of the Organic Fraction of Municipal Solid Wastes in Europe for Different Sorting Strategis and Related Performances of the Anaerobic Digestion Process. Geogr. Environ. Sci. 2002. Available online: https://pdfs.semanticscholar.org/9236/c8478c2eceec9ceea8bdd8e58d528f985b79.pdf?_ga=2.88462290. 839741550.1589966436-616844242.1551145392 (accessed on 4 May 2020).

17. Alvarez, M.D.; Sans, R.; Garrido, N.; Torres, A. Factors that affect the quality of the bio-waste fraction of selectively collected solid waste in Catalonia. Waste Manag. 2008, 28, 359-366. [CrossRef]

18. Cesaro, A.; Russo, L.; Belgiorno, V. Combined anaerobic/aerobic treatment of OFMSW: Performance evaluation using mass balances. Chem. Eng. J. 2015, 267, 16-24. [CrossRef]

19. Cesaro, A.; Belgiorno, V. Pretreatment methods to improve anaerobic biodegradability of organic municipal solid waste fractions. Chem. Eng. J. 2014, 240, 24-37. [CrossRef]

20. Bernstad, A.; Malmquist, L.; Truedsson, C.; la Cour Jansen, J. Need for improvements in physical pretreatment of source-separated household food waste. Waste Manag. 2013, 33, 746-754. [CrossRef] 
21. Koch, K.; Lübken, M.; Gehring, T.; Wichern, M.; Horn, H. Biogas from grass silage - Measurements and modeling with ADM1. Bioresour. Technol. 2010, 101, 8158-8165. [CrossRef]

22. Wichern, M.; Lübken, M.; Horn, H.; Schlattmann, M.; Gronauer, A. Investigations and mathematical simulation on decentralized anaerobic treatment of agricultural substrate from livestock farming. Water Sci. Technol. 2008, 58, 67-72. [CrossRef] [PubMed]

23. Lübken, M.; Gehring, T.; Wichern, M. Microbiological fermentation of lignocellulosic biomass: Current state and prospects of mathematical modeling. Appl. Microbiol. Biotechnol. 2010, 85, 1643-1652. [CrossRef] [PubMed]

24. Biernacki, P.; Steinigeweg, S.; Borchert, A.; Uhlenhut, F.; Brehm, A. Application of Anaerobic Digestion Model No. 1 for describing an existing biogas power plant. Biomass Bioenergy 2013, 59, 441-447. [CrossRef]

25. Pastor-Poquet, V.; Papirio, S.; Steyer, J.-P.; Trably, E.; Escudié, R.; Esposito, G. High-solids anaerobic digestion model for homogenized reactors. Water Res. 2018, 142, 501-511. [CrossRef]

26. Esposito, G.; Frunzo, L.; Panico, A.; Pirozzi, F. Modelling the effect of the OLR and OFMSW particle size on the performances of an anaerobic co-digestion reactor. Process Biochem. 2011, 46, 557-565. [CrossRef]

27. Klocke, M.; Mähnert, P.; Mundt, K.; Souidi, K.; Linke, B. Microbial community analysis of a biogas-producing completely stirred tank reactor fed continuously with fodder beet silage as mono-substrate. Syst. Appl. Microbiol. 2007, 30, 139-151. [CrossRef]

28. Li, Y.; Liu, C.; Wachemo, A.C.; Li, X. Effects of liquid fraction of digestate recirculation on system performance and microbial community structure during serial anaerobic digestion of completely stirred tank reactors for corn stover. Energy 2018, 160, 309-317. [CrossRef]

29. Axaopoulos, P.; Panagakis, P.; Tsavdaris, A.; Georgakakis, D. Simulation and experimental performance of a solar-heated anaerobic digester. Sol. Energy 2001, 70, 155-164. [CrossRef]

30. Hreiz, R.; Adouani, N.; Jannot, Y.; Pons, M.-N. Modeling and simulation of heat transfer phenomena in a semi-buried anaerobic digester. Chem. Eng. Res. Des. 2017, 119, 101-116. [CrossRef]

31. Adouani, N.; Pons, M.-N.; Assaad, A.; Hreiz, R.; Ravard, B.; Pacaud, S. Control of a farm anaerobic digester for agricultural wastes. IFAC-PapersOnLine 2017, 50, 3923-3928. [CrossRef]

32. Fezzani, B.; Cheikh, R.B. Implementation of IWA anaerobic digestion model No. 1 (ADM1) for simulating the thermophilic anaerobic co-digestion of olive mill wastewater with olive mill solid waste in a semi-continuous tubular digester. Chem. Eng. J. 2008, 141, 75-88. [CrossRef]

33. Ozkan-Yucel, U.; Gokcay, C. Application of ADM1 model to a full-scale anaerobic digester under dynamic organic loading conditions. Environ. Technol. 2010, 31, 633-640. [CrossRef] [PubMed]

34. Rathnasiri, P.G. Dynamic Modelling and Simulation of Pilot Scale Anaerobic Digestion Plant Treating Source Separated Food Waste and Effect of Recycling Sludge. Procedia Environ. Sci. 2016, 35, 740-748. [CrossRef]

35. Sadik, K.; Hongtan, L.; Anchasa, P. Heat Exchangers. Selection, Rating, and Thermal Design; CRC press: Boca Raton, FL, USA, 2020.

36. INCROPERA, F.; Dewitt, D. p.; Bergman, T. 1.; lavine, A. s. Fundamentals of Heat and Mass Transfer, 6th ed; John Wiley \& Sons, Inc.: Hoboken, NJ, USA, 2006.

37. Xu, F.; Li, Y.; Ge, X.; Yang, L.; Li, Y. Anaerobic digestion of food waste-Challenges and opportunities. Bioresour. Technol. 2018, 247, 1047-1058. [CrossRef] [PubMed]

38. Kondusamy, D.; Kalamdhad, A.S. Pre-treatment and anaerobic digestion of food waste for high rate methane production-A review. J. Environ. Chem. Eng. 2014, 2, 1821-1830. [CrossRef]

39. Cho, S.-K.; Im, W.-T.; Kim, D.-H.; Kim, M.-H.; Shin, H.-S.; Oh, S.-E. Dry anaerobic digestion of food waste under mesophilic conditions: Performance and methanogenic community analysis. Bioresour. Technol. 2013, 131, 210-217. [CrossRef]

(C) 2020 by the authors. Licensee MDPI, Basel, Switzerland. This article is an open access article distributed under the terms and conditions of the Creative Commons Attribution (CC BY) license (http://creativecommons.org/licenses/by/4.0/). 